\title{
Molecular Characterization, Morphological Characteristics, Virulence, and Geographic Distribution of Rhizoctonia spp. in Washington State
}

\author{
Ahmad Kamil Mohd Jaaffar, Timothy C. Paulitz, Kurtis L. Schroeder, Linda S. Thomashow, and David M. Weller
}

First and third authors: Department of Plant Pathology, Washington State University, Pullman, WA 99164-6430; and second, fourth, and fifth authors: U.S. Department of Agriculture-Agricultural Research Service, Wheat Health, Genetics and Quality Research Unit, Pullman, WA 99164-6430.

Current address of first author: Malaysian Cocoa Board, Biotechnology Park, 94300 Kota Samarahan, Sarawak, Malaysia.

Current address of third author: Department of Plant, Soil and Entomological Sciences, University of Idaho, Moscow 83843.

Accepted for publication 25 December 2015.

\begin{abstract}
Jaaffar, A. K. M., Paulitz, T. C., Schroeder, K. L., Thomashow, L. S., and Weller, D. M. 2016. Molecular characterization, morphological characteristics, virulence, and geographic distribution of Rhizoctonia spp. in Washington State. Phytopathology 106:459-473.

Rhizoctonia root rot and bare patch, caused by Rhizoctonia solani anastomosis group (AG)- 8 and $R$. oryzae, are chronic and important yieldlimiting diseases of wheat and barley in the Inland Pacific Northwest (PNW) of the United States. Major gaps remain in our understanding of the epidemiology of these diseases, in part because multiple Rhizoctonia AGs and species can be isolated from the same cereal roots from the field, contributing to the challenge of identifying the causal agents correctly. In this study, a collection totaling 498 isolates of Rhizoctonia was assembled from surveys conducted from 2000 to 2009, 2010, and 2011 over a wide range of cereal production fields throughout Washington State in the PNW. To determine the identity of the isolates, PCR with AG- or speciesspecific primers and/or DNA sequence analysis of the internal transcribed spacers was performed. $R$. solani AG-2-1, AG-8, AG-10, AG-3, AG-4, and AG-11 comprised 157 (32\%), 70 (14\%), 21 (4\%), 20 (4\%), $1(0.2 \%)$, and $1(0.2 \%)$, respectively, of the total isolates. AG-I-like binucleate Rhizoctonia sp. comprised 44 (9\%) of the total; and 53 (11\%), 80 (16\%),

and $51(10 \%)$ were identified as $R$. oryzae genotypes I, II, and III, respectively. Isolates of AG-2-1, the dominant Rhizoctonia, occurred in all six agronomic zones defined by annual precipitation and temperature within the region sampled. Isolates of AG-8 also were cosmopolitan in their distribution but the frequency of isolation varied among years, and they were most abundant in zones of low and moderate precipitation. $R$. oryzae was cosmopolitan, and collectively the three genotypes comprised $37 \%$ of the isolates. Only isolates of $R$. solani AG- 8 and $R$. oryzae genotypes II and III (but not genotype I) caused symptoms typically associated with Rhizoctonia root rot and bare patch of wheat. Isolates of AG-2-1 caused only mild root rot and AG-I-like binucleate isolates and members of groups AG-3, AG-4, and AG-11 showed only slight or no discoloration of the roots. However, all isolates of AG-2-1 caused severe damping-off of canola, resulting in $100 \%$ mortality. Isolates of Rhizoctonia AG-8, AG-2-1, AG-10, AG-I-like binucleate Rhizoctonia, and $R$. oryzae genotypes I, II, and III could be distinguished by colony morphology on potato dextrose agar, by PCR with specific primers, or by the type and severity of disease on wheat and canola seedlings, and results of these approaches correlated completely. Based on cultured isolates, we also identified the geographic distribution of all of these Rhizoctonia isolates in cereal-based production systems throughout Washington State.
\end{abstract}

Rhizoctonia root rot and bare patch of wheat and barley, diseases caused by the soilborne basidiomycete pathogens Rhizoctonia solani Kühn (Thanatephorus cucumeris) anastomosis group (AG)-8 (MacNish and Neate 1996; Neate and Warcup 1985; Weller et al. 1986 ) and $R$. oryzae Ryker \& Gooch (Waitea circinata) (Mazzola et al. 1996; Ogoshi et al. 1990), were first observed in the United States in an irrigated winter wheat field in northeastern Oregon in 1984 (Weller et al. 1986; Pumphrey et al. 1987) and since then have become widespread in direct-seeded (no-till) small grains in the Inland Pacific Northwest (PNW) (Paulitz et al. 2002, 2010a). Symptoms of Rhizoctonia infection were first recognized in Australia, where they initially were described as "purple patch" (Hynes 1933; MacNish and Neate 1996). Disease severity has long been linked directly to a reduction in tillage (Pumphrey et al. 1987; Rovira 1986; Schroeder and Paulitz 2006; Smiley et al. 1996; Weller et al. 1986), a practice promoted in the PNW to control soil erosion. The most severe manifestation of the diseases, "bare patch,"

Corresponding authors: D. M. Weller; E-mail addresses: david.weller@ars.usda.gov andwellerd@wsu.edu, and L. S. Thomashow; E-mail address: linda.thomashow@ ars.usda.gov

http://dx.doi.org/10.1094/PHYTO-09-15-0208-R

This article is in the public domain and not copyrightable. It may be freely reprinted with customary crediting of the source. The American Phytopathological Society, 2016. occurs in direct-seeded (no-till) spring wheat and barley in the low (150 to $300 \mathrm{~mm}$ annually) and intermediate ( 300 to $450 \mathrm{~mm}$ ) precipitation zones of the Columbia Plateau of the Inland PNW (Paulitz et al. 2010a). Patches of severely stunted plants with delayed maturity and occasional seedling death can vary in size from only a few centimeters to many meters in diameter, and in severe cases entire fields can become a single patch. In higher precipitation zones (>450 $\mathrm{mm})$ such as the Palouse region of far eastern Washington State and northern Idaho, bare patches are less common and Rhizoctonia root rot appears as reduced vigor and unevenness in plant height throughout the field (Paulitz et al. 2002).

$R$. solani AG-8 and $R$. oryzae survive in living plants and persist in roots of volunteer wheat, barley, and grassy weeds (Paulitz et al. 2002; Smiley et al. 1992). These pathogens attack seminal and crown roots causing brown sunken lesions in which the root cortex is collapsed, leaving only the stele. Lesions may eventually girdle and sever roots, leaving "pinched-off" pointed brown tips ("needle points" or "spear tips") (Weller et al. 1986). The roots appear pruned, and severely infected seedlings become yellow, necrotic, stunted, and can die prematurely, leading to patch development. Alternatively, when sufficient water is available, stunted plants can persist in bare patches, giving rise to highly visible green patches in the stubble following harvest (Smiley and Wilkins 1993). Whereas R. solani is the more aggressive pathogen in bare patch (Smiley and Uddin 1993), $R$. oryzae is more aggressive in causing damping-off (Mazzola et al. 
1996; Paulitz et al. 2003; Schroeder and Paulitz 2008). Both pathogens have wide host ranges and also attack broadleaf crops (Davis 2005; Paulitz 2002; Paulitz et al. 2010a). R. solani AG-8 also causes bare patches in irrigated onions and peas grown in rotation with wheat (Patzek et al. 2013; Sharma-Poudyal et al. 2015a, 2015b).

There is no genetic resistance to Rhizoctonia root rot in commercial wheat and barley varieties (Paulitz et al. 2002; Smith et al. 2003a), although $R$. oryzae shows cultivar by isolate interactions (Paulitz et al. 2003). Chemical seed treatments provide limited control but only during the seedling phase of the disease (Cook et al. 2002; Paulitz et al. 2010a). As a result, research on Rhizoctonia root rot and bare patch has focused on cultural practices to manage the diseases (Cook 2001; MacNish 1985; Paulitz et al. 2010a; Roget et al. 1987, 1996; Smiley et al. 1992), with tillage being the most effective (Paulitz et al. 2010b; Schroeder and Paulitz 2006, 2008), yet it is discouraged because it promotes soil erosion. Also highly effective is "greenbridge" management (Babiker et al. 2011; Paulitz et al. 2010a; Smiley et al. 1992), which reduces the carryover of pathogen from crop volunteer and grassy weeds to the new crop. Application of starter fertilizer in the seed row also can ameliorate the effects of Rhizoctonia root rot by enabling the plants to overcome early nutrient deficiencies caused by root pruning (Smiley et al. 1990).

Besides $R$. solani AG-8 and $R$. oryzae, members of other hyphal AGs and species have been reported in PNW cereal-based cropping systems including $R$. solani AG-2-1, AG-3, AG-4, AG-9, and AG-10; and binucleate Rhizoctonia sp. AG-CI, AG-D, AG-E, AG-H, AG-I-like, and AG-K (Ogoshi et al. 1990; Okubara et al. 2008; Paulitz et al. 2006). Some of these Rhizoctonia groups can cause trace to mild damage on cereals, and their role in the epidemiology of root rot and bare patch and interactions with AG-8 and R. oryzae is still unclear. For example, AG-2-1 causes severe pre- and postemergence damping-off of canola (Paulitz et al. 2006) and some isolates including those of $R$. oryzae also have a broad host range (Paulitz et al. 2010a) and stunt peas and lentils (Paulitz 2002; Sharma-Poudyal et al. 2015b). These crops are commonly grown in rotation with wheat and barley in Washington State.

Traditionally, Rhizoctonia groups and species found in PNW soils have been distinguished by colony morphology, pathogenicity tests, nuclear status (binucleate or multinucleate) and hyphal AG reactions (Carling et al. 2002; Demirci 1998; Ogoshi 1987; Ogoshi et al. 1990; Weller et al. 1986). Okubara et al. (2008) developed SYBR Green I-based Q-PCR assays specific to internal transcribed spacers (ITS) 1 and ITS2 of the ribosomal DNA of $R$. solani and $R$. oryzae that were diagnostic for $R$. solani AG-2-1, AG-8, AG-10, three genotypes of $R$. oryzae, and AG-I-like binucleate Rhizoctonia species. These assays have been used to detect and quantify DNA of $R$. solani AG-8 and $R$. oryzae genotype III in soil, and to establish relationships between soil DNA concentration and agroecological factors (Okubara et al. 2014) including precipitation, temperature maxima and minima, and soil texture. Similarly, Poole et al. (2015) showed recently that soil DNA of $R$. solani AG-8, soil temperature, and rainfall explained most of the variation in cereal root health at anthesis in Western Australia.

Despite over 25 years of research on Rhizoctonia root rot and bare patch in the PNW, Rhizoctonia diseases remain the primary barrier to the wider adoption of direct-seeded cereal-based cropping systems that are solutions to soil loss in this highly erodible region of the United States (Schillinger and Paulitz 2006). Major gaps exist in our knowledge about the distribution and biogeography of Rhizoctonia species/AGs, their morphology in culture, genetic diversity, virulence, host range, and contribution to root rot and bare patch. One reason for these gaps is that historically, AG-8 is difficult to isolate from soil and even from diseased tissue (Harris and Moen 1985; Paulitz and Schroeder 2005; D. M. Weller, unpublished data), which prompted Harris and Moen (1985) in Australia to question the role of AG-8 in root rot and bare patch. Secondly, the fact that many other AGs of $R$. solani and other species of Rhizoctonia (which can also damage roots) can be isolated from diseased roots and bare patches adds to the confusion about these diseases and the causal agent(s). Paulitz and Schroeder (2005) developed a toothpick assay which greatly enhanced the ability to collect Rhizoctonia isolates from soil, and when paired with Q-PCR assays (Okubara et al. 2008), it can be used to assess the density and diversity of AGs and species in cereal-based cropping systems. Recently, Okubara et al. (2014) bypassed direct isolation of Rhizoctonia and used Q-PCR assays of soil DNA to estimate populations of Rhizoctonia AG-8 and $R$. oryzae genotype III in Washington fields. They found that DNA of $R$. solani AG- 8 was greatest in the low- and intermediateprecipitation zones and least in higher-precipitation zones, while $R$. oryzae concentrations were correlated with temperature minima but not with precipitation. Both pathogens were more abundant in soils with higher sand and lower clay content.

The overarching goal of the current study was to fill the gap in knowledge about the virulence and biogeography of Rhizoctonia species/AGs in cereal-based cropping systems using isolates from the field. One objective was to develop simple and consistent approaches based on colony morphology, PCR with specific primers, and the type and severity of disease on wheat and canola seedlings in order to identify AG-8 isolates and to distinguish them from other Rhizoctonia in dryland cropping systems. The second objective was to determine the geographic distribution of $R$. solani AG-8, AG-2-1, and $R$. oryzae, the most pathogenic isolates on cereals and/or broadleaf crops in the cereal-based production systems of Washington State.

\section{MATERIALS AND METHODS}

Isolation, culture, and storage of Rhizoctonia spp. Rhizoctonia spp. (201 isolates) were randomly selected from an existing collection of T. Paulitz (USDA-ARS, Pullman, WA). These isolates were recovered directly from roots or from soil samples by using a toothpick assay (Paulitz and Schroeder 2005) (see below) during his surveys of fields and crops in the low (150 to $300 \mathrm{~mm}$ annually), intermediate $(300$ to $450 \mathrm{~mm})$, and high $(>450 \mathrm{~mm})$ precipitation zones of the Columbia Plateau of the Inland PNW between July 2000 and April 2009. For the current study, additional Rhizoctonia isolates were collected in the summers of 2010 (117 isolates) and 2011 (180 isolates) by using the toothpick assay from soil samples taken from some of the same fields that Paulitz sampled between 2000 and 2009. From each field, soil from random locations was dug with a shovel to a depth of about $20 \mathrm{~cm}$ (approximately $1 \mathrm{~kg}$ per sample) and each sample (replicate) was placed in a separate labeled plastic bag. Soil samples were stored at $4^{\circ} \mathrm{C}$ overnight and processed the next day.

For the toothpick baiting assay (Paulitz and Schroeder 2005), soil $(200 \mathrm{~g})$ from each replicate from each field was placed in a pot (7.2 cm diameter $\times 6.2 \mathrm{~cm}$ height), $20 \mathrm{ml}$ of water was added, and the pots were incubated in a growth room at $16^{\circ} \mathrm{C}$. After 2 days, five flat wooden toothpicks ( $6 \mathrm{~cm}$ long by 1 to $2 \mathrm{~mm}$ wide; Diamond Brands, Minneapolis, MN) were inserted (evenly spaced) into the soil of each pot to a depth of $5 \mathrm{~cm}$, and the pots were incubated for another 2 days. The toothpicks were removed and placed on plates of a Rhizoctonia-selective medium (RSM) (Paulitz and Schroeder 2005) (five toothpicks per plate), and incubated at room temperature for $24 \mathrm{~h}$. RSM is water agar consisting of $20 \mathrm{~g}$ of agar (SigmaAldrich, St. Louis, MO)/1 liter of deionized water, supplemented with chloramphenicol at $100 \mu \mathrm{g} / \mathrm{ml}$ (Research Product International Corp., Mt Prospect, IL) and benomyl at $1 \mu \mathrm{g} / \mathrm{ml}$ a.i. (Benlate, DuPont, Wilmington, DE). Plates were examined under a dissecting microscope (Olympus SZ, 10 to 40×, Japan) and emerging hyphae with characteristics of Rhizoctonia were transferred to water agar (WA) and then to potato dextrose agar (PDA) (24 g of potato dextrose broth [PDB; Difco, Sparks, MD], $20 \mathrm{~g}$ of agar and water, 1 liter). In some cases, isolates were transferred multiple times on WA to purify them before transfer to PDA. Rhizoctonia isolates were routinely cultured on PDA and stored on slants in glass screwcapped tubes at $4^{\circ} \mathrm{C}$. 
DNA extraction and identification of Rhizoctonia AGs and species by PCR. Rhizoctonia isolates were grown in $25 \mathrm{ml}$ of PDB (24 g) and water (1 liter) in Petri dishes for 7 days at room temperature without shaking. PDB was inoculated by placing an agar plug $(1 \mathrm{~cm}$ diameter $\times 0.5 \mathrm{~cm}$ thick) taken from a 7-day-old culture grown on fresh PDA. After 7 days, the medium was poured off and the mycelial mat was washed twice with $15 \mathrm{ml}$ of sterile deionized water and blotted on sterile filter paper $(125 \mathrm{~mm}$ diameter; Whatman No. 4). The mycelium then was placed into a 1.5-ml FastDNA tube and either processed immediately or stored at $-20^{\circ} \mathrm{C}$ for later processing.

DNA was extracted using the FastDNA Kit (MP Biomedicals, LLC) according to the manufacturer's protocol and amplified by conventional PCR using primers (Eurofins MWG Operon, Huntsville, $\mathrm{AL}$ ) that were originally designed for Q-PCR (Okubara et al. 2008) and are specific to the ITS1 and ITS2 of the nuclear ribosomal DNA of $R$. solani AG-8, AG 2-1, and AG-10; AG-I-like binucleate Rhizoctonia sp.; and R. oryzae genotypes I, II, and III (Table 1). PCR assays ( $15 \mu \mathrm{l})$ contained $7.7 \mu \mathrm{l}$ of deionized water, $5 \times$ Green GoTaq Flexi buffer (Promega Corporation, Madison, WI), $0.13 \mathrm{mM}$ dNTPs, $1.5 \mathrm{mM} \mathrm{MgCl}_{2}, 6 \mathrm{pmol}$ each of forward and reverse primer, 1 unit of Taq polymerase (Promega Corporation, Madison, WI), and $1 \mu \mathrm{l}$ of DNA template. The PCR program consisted of an initial denaturation step at $94^{\circ} \mathrm{C}$ for 3 min followed by 35 amplification cycles, including denaturation at $92^{\circ} \mathrm{C}$ for $45 \mathrm{~s}$, annealing at 63,62 , $54,54,57,60$, or $60^{\circ} \mathrm{C}$ for $45 \mathrm{~s}$ for DNA of AG-8, AG-2-1, AG-10, AG-I, or $R$. oryzae genotype I, II, or III, respectively, and extension at $72^{\circ} \mathrm{C}$ for $10 \mathrm{~min}$. PCR was performed with an MJ Research PTC-200 thermal cycler (Bio-Rad, Hercules, CA). All the isolates were identified based on different PCR amplicon sizes: a 441-bp fragment indicated $R$. solani AG-2-1; a 327-bp fragment indicated AG-8, a 432-bp fragment indicated AG-10, a 123-bp fragment indicated AG-I-like binucleate Rhizoctonia sp., a 437-bp fragment indicated $R$. oryzae genotype I, a 289-bp fragment indicated genotype II, a 286-bp fragment indicated genotype III, and no PCR fragment indicated another AG or species (Okubara et al. 2008). PCR amplicons were visualized by electrophoresis in a $1.0 \%$ agarose gel stained with ethidium bromide.

Sequence analysis of ITS. Rhizoctonia ITS rDNA was amplified by PCR from purified fungal DNA using UN-UP18S42 and UN-LO28S576B primers as described by Bakkeren et al. (2000). Reactions consisted of $2 \mu \mathrm{l}$ of fungal DNA, 5x GoTaq Buffer (Promega Corporation), $1.5 \mathrm{mM} \mathrm{MgCl}_{2}, 0.2 \mathrm{mM} \mathrm{dNTPs}, 12 \mathrm{pmol}$ of each primer, and 1.5 units of GoTaq DNA polymerase (Promega Corporation) in a total volume of $30 \mu \mathrm{l}$. PCR was performed with an MJ Research PTC-200 thermocycler at $94^{\circ} \mathrm{C} 3 \mathrm{~min}(1$ cycle $) ; 94^{\circ} \mathrm{C}$ for $45 \mathrm{~s}, 60^{\circ} \mathrm{C}$ for $45 \mathrm{~s}, 72^{\circ} \mathrm{C}$ for $60 \mathrm{~s}$ ( 32 cycles $) ; 72^{\circ} \mathrm{C}$ for $10 \mathrm{~min}(1$ cycle); and $4^{\circ} \mathrm{C}$ soak (Schroeder et al. 2006). After amplification, an aliquot of each reaction was separated by electrophoresis on a $1 \%$ agarose gel and amplicon band size was verified. Approximately 20 to $30 \mathrm{ng}$ of amplified Rhizoctonia ITS DNA was combined with 8 pmol UN-UP18S42 primer in a total volume of $15 \mu$ l. These samples were sequenced by ELIM Biopharmaceuticals (San Francisco, CA). ITS nucleotide sequences from Washington State isolates were compared with annotated GenBank accessions using BLAST (www.ncbi.nlm.nih.gov/BLAST). Only reference sequences for which refereed publications are available were used for assigning AGs and a minimum match of $97 \%$ identity was required for assignment to a specific AG or species.

Colony morphology of $\boldsymbol{R}$. solani, binucleate Rhizoctonia, and $\boldsymbol{R}$. oryzae. Mycelial plugs $(0.5 \mathrm{~cm} \times 0.7 \mathrm{~cm})$ of each $R$. solani isolate (AG-8, AG-2-1, and AG-10), AG-I-like binucleate Rhizoctonia sp., and $R$. oryzae genotype I, II, and III were transferred from the edge of 7-day-old cultures growing on PDA to fresh PDA $(25 \mathrm{ml}$ of medium per plate). Each isolate from each group was replicated three times (three plates/isolate). Plates were incubated in the dark at $24^{\circ} \mathrm{C}$ for 7 days before evaluation, and then for up to 30 days. The colony characteristics (colony color, prominence of concentric rings of growth, and shape and color of sclerotia) of each isolate were recorded.

Determination of virulence and pathogenicity. Selected isolates of $R$. solani (AG-8, AG-2-1, and AG-10), R. oryzae (genotypes I, II, and III), and AG-I-like binucleate Rhizoctonia sp. were tested for pathogenicity and virulence on wheat (Triticum aestivum 'Louise') and canola (Brassica napus 'TR8') by using a modification of the 'tube assay' previously described by Kwak et al. (2009). Briefly, the assays were conducted in plastic tubes $(2.5 \mathrm{~cm}$ wide at the top $\times$ $16.5 \mathrm{~cm}$ height; Cone-tainers, Canby, OR), plugged at the bottom with a cotton ball, and hung in plastic racks (200 tubes per rack). Each tube was filled with a $10-\mathrm{cm}$ column of sterilized vermiculite and then a 2-cm-layer of pasteurized soil $\left(60^{\circ} \mathrm{C}, 30 \mathrm{~min}\right)$ from Quincy, WA (Shano sandy loam). Three agar plugs (5-mm diameter), cut from a plate of PDA colonized by an isolate, were added on the top of the soil layer and then covered with a 1-cm-layer of vermiculite. Controls consisted of tubes with plugs of PDA without mycelium. Three wheat seeds or 10 canola seeds were placed on the vermiculite and covered with a 1-cm-layer of vermiculite. Each tube received $10 \mathrm{ml}$ of water containing metalaxyl ( $0.075 \mathrm{~g}$ of wettable powder liter ${ }^{-1}$ of tap water; Syngenta, Wilmington, DE) to suppress indigenous Pythium spp. that can cause damping-off and interfere with disease ratings. For each isolate, three replicates of five tubes each were prepared and arranged in a randomized complete block design. The racks of tubes were covered with transparent plastic for 5 days at $24^{\circ} \mathrm{C}$ before being moved into a growth room at $16^{\circ} \mathrm{C}$ with a 12 -h photoperiod (Kwak et al. 2009). After emergence, the plastic was removed and plants were watered twice weekly with $12 \mathrm{ml}$ of water and once with $1 / 3$ strength Hoagland's solution (macroelements only) as previously described by Kwak et al. (2009). Four weeks after planting, plants

TABLE 1. Polymerase chain reaction (PCR) primers used for amplification of Rhizoctonia solani, $R$. oryzae, and anastomosis group (AG)-I-like binucleate Rhizoctonia (teleomorph Ceratobasidium) ${ }^{\mathrm{z}}$

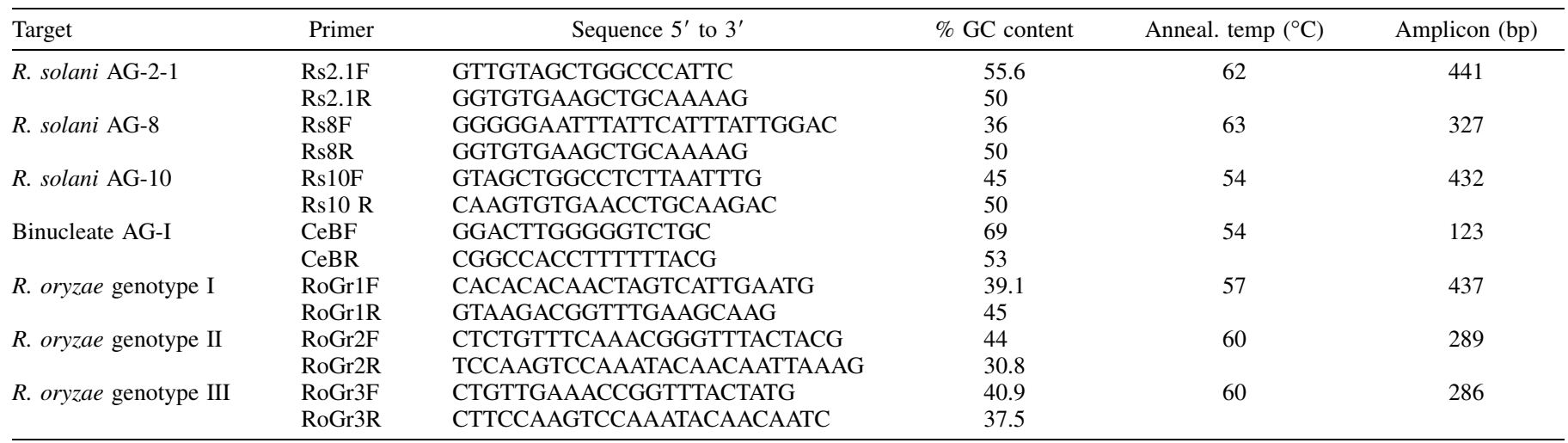

$\mathrm{z}$ Table was modified from Okubara et al. (2008). 
were removed from the tubes and washed under a stream of water prior to evaluation of disease symptoms. All experiments were repeated in time.

The amount of disease caused by each isolate on wheat and canola was determining by assessing root rot, pre- and postemergence damping-off, and plant survival and/or plant height. The severity of root rot was rated on a scale of 0 to 8 (Huang et al. 2004), where $0=$ healthy/uninfected (disease not evident) and $8=$ dead plant. This rating scale considers both root disease and the health of the foliage. Disease severity on canola was recorded based on numbers of surviving and dead seedlings.

Pathogen inoculum. Inocula of $R$. solani AG-8, AG 2-1, and AG-10; AG-I-like binucleate Rhizoctonia sp.; and three genotypes of $R$. oryzae used in the tube assay were grown on PDA at room temperature $\left(24^{\circ} \mathrm{C}\right)$ and kept in the dark. Seven days after a plate of PDA was inoculated (plug placed in the center of plate), 5-mm agar plugs were cut with a cork borer from the outer edge of the plate and immediately added to the cones. This approach gave consistent disease in repeated experiments.

Geographic distribution of Rhizoctonia isolates. Maps of the agronomic zones in the Inland PNW (Douglas et al. 1990, 1992) based on climatic zones, annual precipitation, growing degree days, and soil depth were used to display the distribution of $R$. solani AGs, AG-I-like binucleate Rhizoctonia sp., and R. oryzae. A description of these zones is shown in Table 2. Sampled locations were recorded according to their global positioning system (GPS) coordinates and maps were constructed by using ArcGIS 9.3.1 software (ESRI, Redlands, CA).
Statistical analysis. For pathogenicity and virulence tests, treatments were conducted in a randomized complete block design and data were analyzed using STATISTIX 8.0 software (Analytical Software, St. Paul, MN). Differences in root disease (disease rating) and plant height among treatments were determined by standard analysis of variance and mean comparisons among treatments were performed by using Fisher's protected least significant difference test $(P=0.05)$ or by the Kruskal-Wallis test $(P=0.05)$.

\section{RESULTS}

Conventional PCR of DNA of Rhizoctonia isolates. PCR primers, adapted from those developed by Okubara et al. (2008) for Q-PCR assays and specific for $R$. solani (AG-2-1, AG-8, and AG-10), AG-I-like binucleate Rhizoctonia sp., and $R$. oryzae (genotypes I, II, and III), amplified fragments of 441, 327, 432, 123, 437, 289, and $286 \mathrm{bp}$, respectively, from DNA of these isolates (Table 1). For example, Figure 1 shows the bands associated with AG- 8 isolate C-1 and five putative AG- 8 isolates, AG-2-1 isolate Rh0810015, and four putative AG-2-1 isolates, AG-10 isolate Rh080750 and four putative AG-10 isolates, AG-I-like binucleate Rhizoctonia sp. Rh070716 and five putative AG-I isolates, and $R$. oryzae genotype II isolate Rh1202283 and five putative genotype II isolates. Examples of the bands generated by primers specific for $R$. oryzae genotypes I and III are not shown.

Okubara et al. (2008) indicated that primers Rs8F and Rs8R were specific for AG-8 isolates. However, we found that when using larger quantities of DNA and an annealing temperature of $62^{\circ} \mathrm{C}$,

TABLE 2. Characteristics of Inland Pacific Northwest agronomic zones

\begin{tabular}{|c|c|c|c|c|}
\hline Agronomic zone ${ }^{v}$ & Characteristics of climatic zones ${ }^{\mathrm{w}}$ & Annual precipitation $(\mathrm{mm})^{\mathrm{x}}$ & Growing degree days (GDD)y & Soil depth $(\mathrm{cm})^{\mathrm{z}}$ \\
\hline 1 & Cold-moist & $>400$ & $<700$ & - \\
\hline 2 & Cool-moist & $>400$ & $700-1,000$ & - \\
\hline 3 & Cool-deep-moderately dry & $350-400$ & $700-1,000$ & $>102.6$ \\
\hline 4 & Cool-shallow-dry & $250-400$ & $<1,000$ & $<102.6$ \\
\hline 5 & Cool-deep-dry & $250-350$ & $<1,000$ & $>102.6$ \\
\hline 6 & Hot-very dry irrigation required & $<250$ & $>1,000$ & - \\
\hline
\end{tabular}

v Agronomic zones were developed by Douglas et al. $(1990,1992)$ on the basis of climatic region, annual precipitation, growing degree days and soil depth.

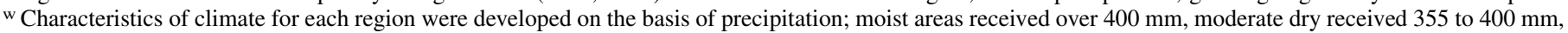
shallow dry received 250 to 400 , deep dry 250 to $350 \mathrm{~mm}$, and very dry received under $250 \mathrm{~mm}$.

x Precipitation records were obtained from National Weather Service based on 30-year records.

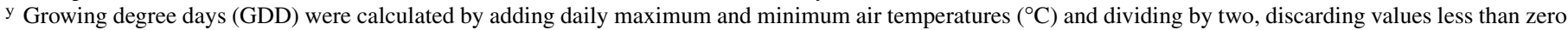
and summing the daily GDD values accumulated from 1 January through 31 May.

z Soil depth was divided into two classes: deep (over $100 \mathrm{~cm}$ ) and shallow (under $100 \mathrm{~cm}$ ).

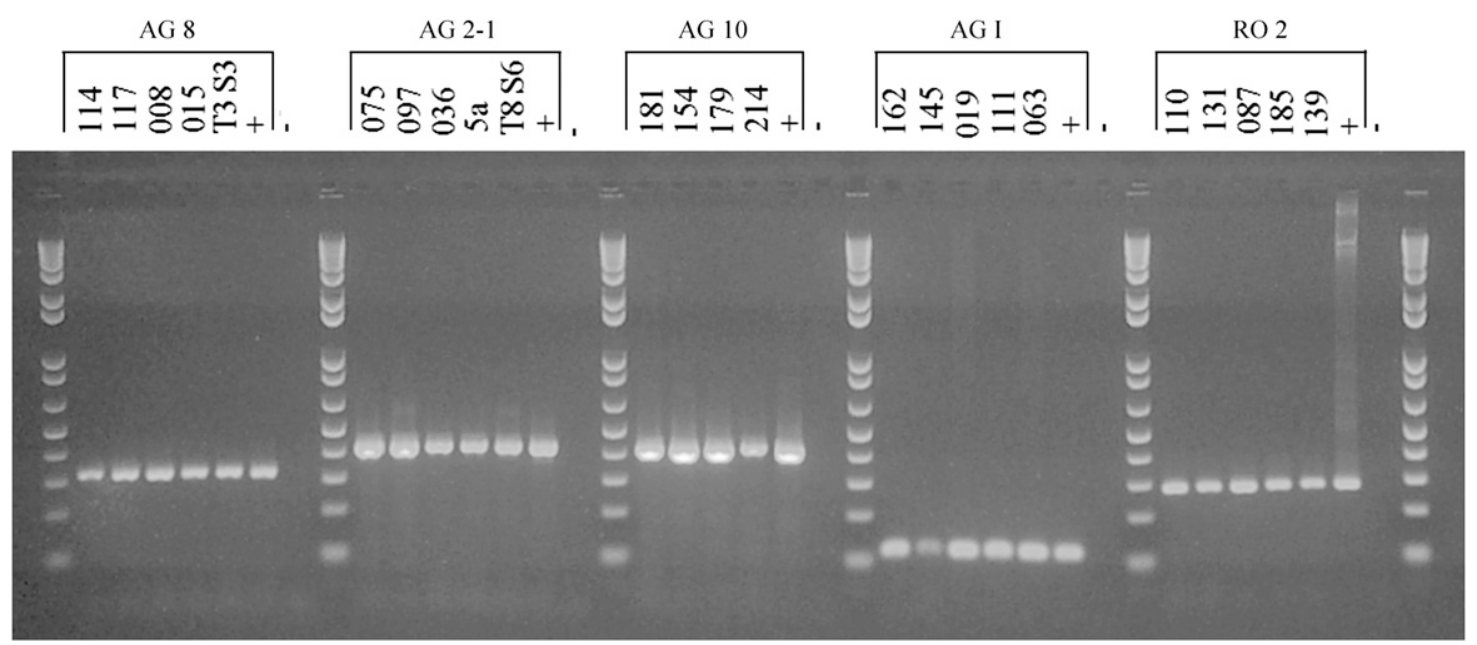

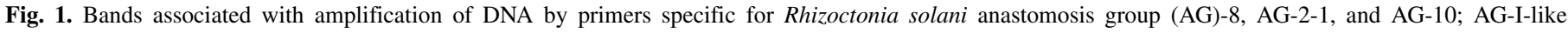

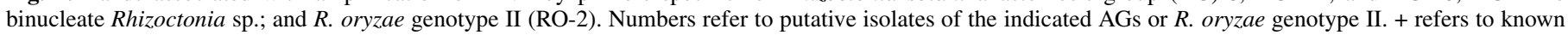

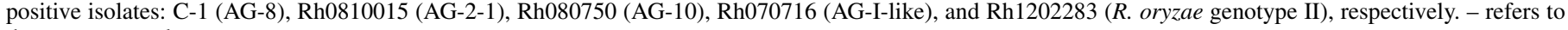
the water control. 
these primers also weakly amplified AG-2-1 rDNA. By increasing the annealing temperature to $63^{\circ} \mathrm{C}$ and then to $64^{\circ} \mathrm{C}$, nearly all cross reactions were eliminated (Fig. 2). To confirm the validity of the primers specific for AG-2-1 and AG-8, the ITS region of 40 isolates was sequenced and a perfect correlation was found between identifications based on DNA sequence of the ITS fragment and its presence after amplification at the appropriate temperature (Tables 1 and 3).

Colony characteristics of Rhizoctonia isolates. The colony characteristics of $R$. solani (AG-2-1, AG-8, and AG-10), AG-I-like binucleate Rhizoctonia sp., and $R$. oryzae genotypes I, II, and III were evaluated for morphological features including color of mycelium, concentric rings of radial growth, and color and shape of sclerotia. After 7 days of growth in the dark at $24^{\circ} \mathrm{C}$, isolates of each AG or species showed distinctive and reproducible colony morphology characteristics throughout the course of this study as long as the conditions for growth were maintained.

Of special interest were AG-2-1 and AG- 8 because they were the most common $R$. solani isolated. They were the most virulent AGs on canola and wheat, respectively, (see below) and they previously have been considered to have similar colony characteristics. After 7 days of growth, the colony of AG-2-1 was light brown with cottony aerial mycelium and prominent concentric rings of radial growth (Fig. 3A and C). In contrast, the colony of AG-8 was creamy to light brown with less cottony aerial mycelium and the concentric rings of radial growth were less prominent (Fig. 3B and D). After 30 days, the colony of AG-2-1 was darker in color than that of AG-8 (Fig. 3E and F). In colonies of AG-2-1 and AG-8, sclerotia were not common.

Twenty isolates each of AG-2-1 and AG-8 were characterized from the three Rhizoctonia collections (2000 to 2009, 2010, and 2011) (Table 3) to insure that these morphological traits were consistent with isolate identity by PCR and DNA sequence analysis. All isolates showed the colony characteristics seen in Figure 3. In addition, all 20 AG-8 isolates were similar to isolate C-1, which in 1984, was one of the first AG-8 isolates collected in the PNW (D. M. Weller, unpublished data) and has been used in studies of Rhizoctonia for over 25 years (Mazzola 1997; Mazzola et al. 1996; Okubara and
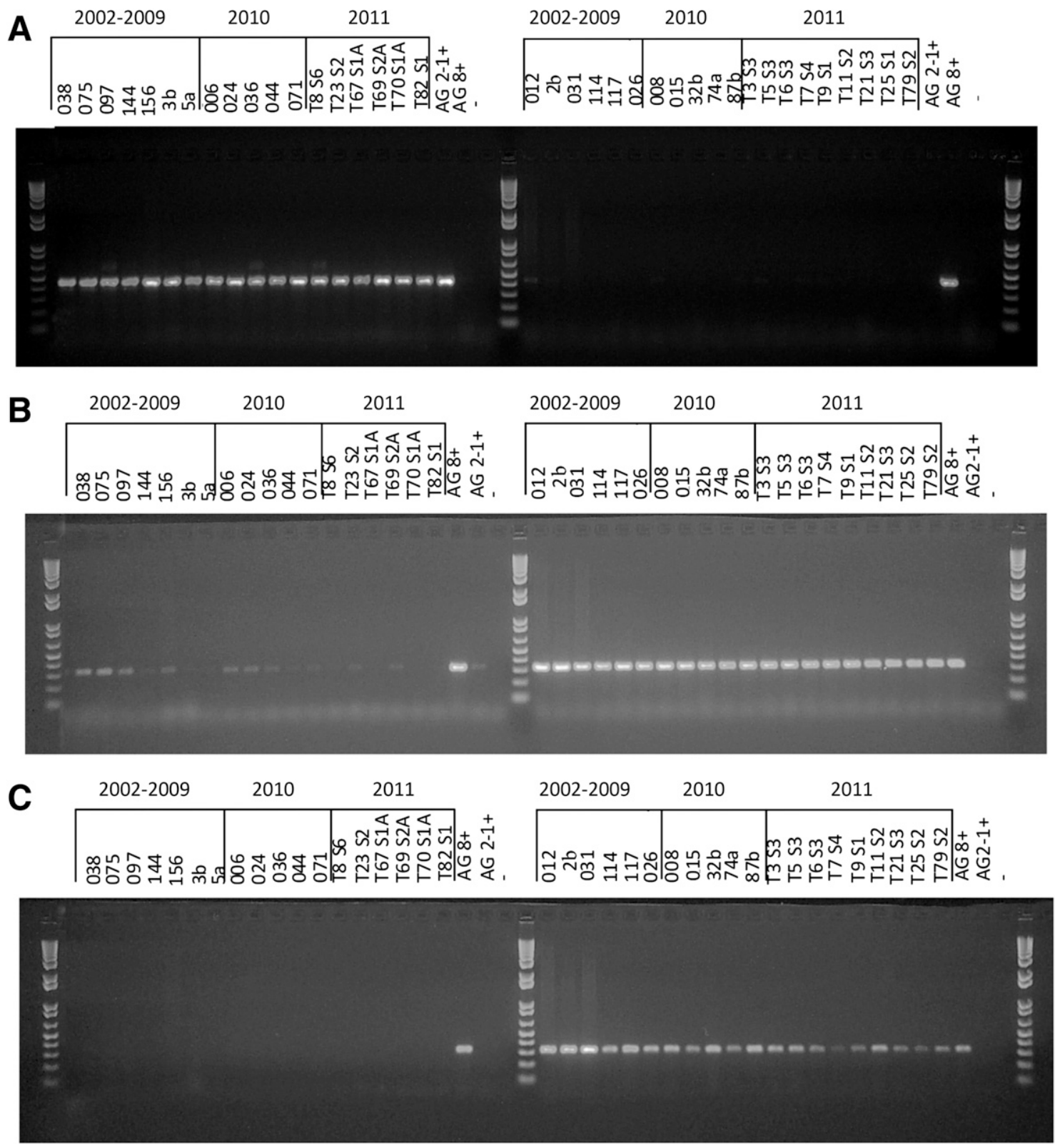

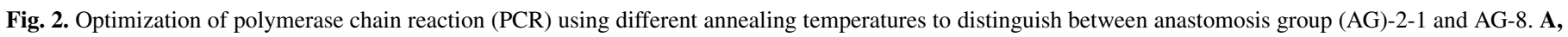

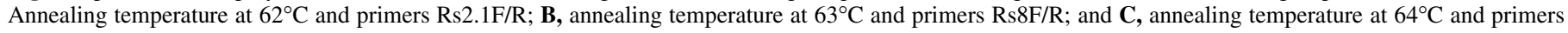
Rs8F/Rs8R. 
Jones 2011; Okubara et al. 2008; Paulitz and Schroeder 2005; Smith et al. 2003a, b). Assignments based on visual assessments of colony morphology correlated completely with those based on PCR, sequencing and virulence data (Table 3) (see below).

Both $R$. solani AG-10 and AG-I-like binucleate Rhizoctonia sp. isolates showed concentric rings of radial growth on PDA at 7 days but the rings of the former were much more prominent. The color of the AG-10 colony was light brown with thick cottony aerial mycelium that was silky. The color of the AG-I-like colony was creamy to light brown with submerged mycelium and a moist appearance. At 30 days, the color of the AG-I-like isolate had turned light yellow.

AG-2-1 and AG-10 isolates both produced prominent concentric rings of radial growth but they were easily distinguished by the width of the rings. Those of AG-10 were much wider and they had more cottony aerial mycelium and were silky. Thirty-day-old cultures of AG-2-1 were darker than those of AG-10, which changed from light brown (at 7 days) to brown and became more cottony.

At 7 days, AG-8 and AG-I-like isolates were easily distinguished on the basis of aerial mycelium. AG-I-like isolates produced much

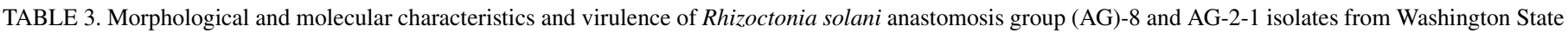

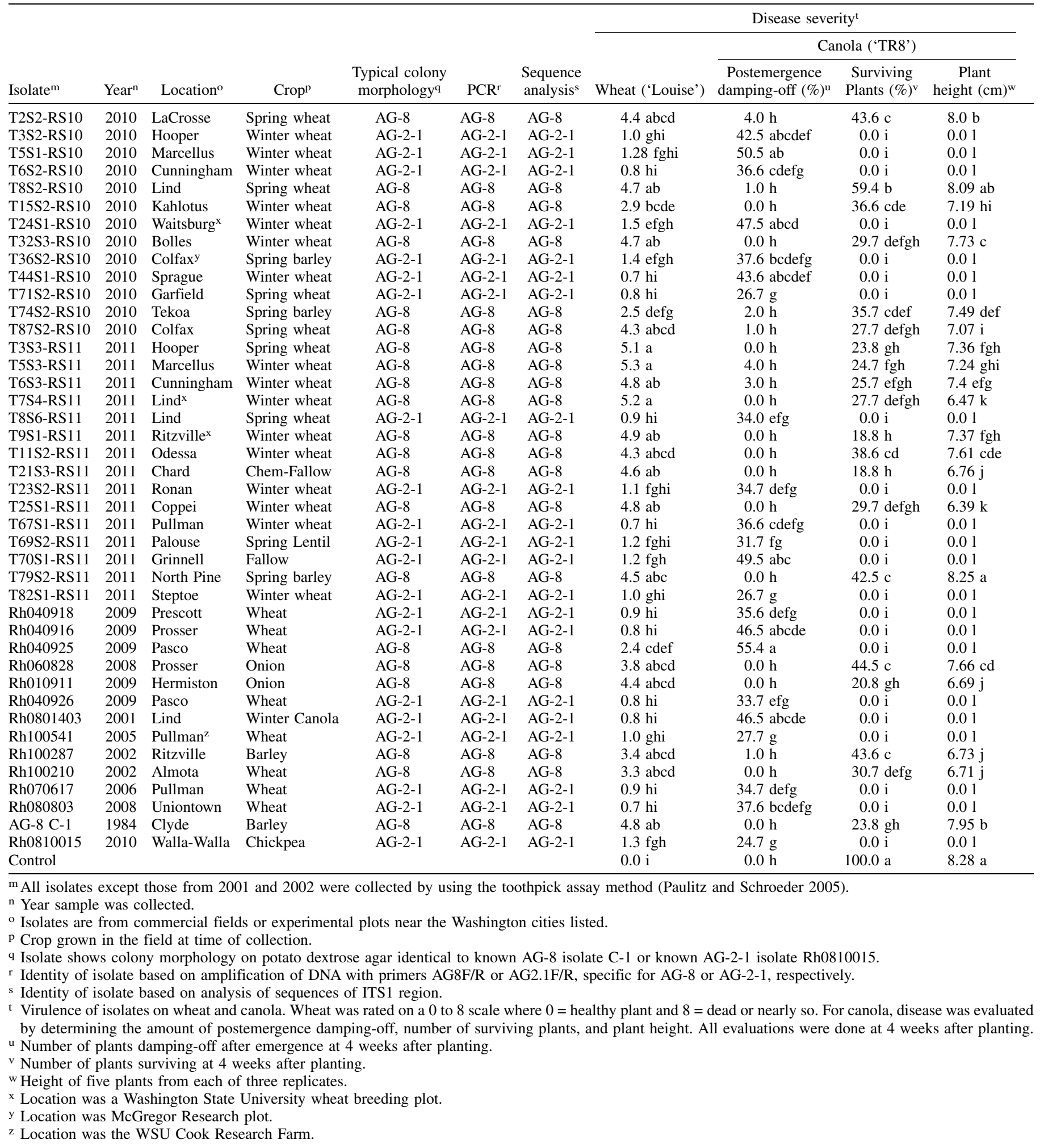


more cottony aerial mycelium than did AG-8 isolates, and AG-Ilike mycelium had a moist appearance and produced submerged mycelium. At 30 days, the colony of AG-8 was brown with clear concentric rings of growth, whereas AG-I was light yellow and the growth rings were whitish.

$R$. oryzae isolates were prolific producers of sclerotia (compact masses of monilioid cells), which allowed them to be easily distinguished from $R$. solani and AG-I-like binucleate Rhizoctonia sp. Isolates of $R$. oryzae genotypes I, II, and III were distinguished from one other by the color and shape of their sclerotia and mycelial color. At 7 days, sclerotia of genotype I isolates were orange to brown in color and globose; genotype II sclerotia were orange to salmon in color with an irregular shape; and genotype III sclerotia were light brown to brown with a regular shape. At 30 days, the color of sclerotia of isolates of genotypes I and III were dark brown but the sclerotia of genotype II isolates remained orange. At 7 days, the mycelium of all three genotypes was light brown in color. At 30 days, the colonies of genotype I and III isolates were brown but genotype II isolates did not change color. Visual assessment of colony morphology always correlated with PCR, sequencing and virulence data (see below). Individuals not familiar with Rhizoctonia were able to use the images in Figures 3, 4, and 5 to identify the Rhizoctonia isolates at 7 days. It is noteworthy that analysis of the ITS sequences indicated that $R$. oryzae genotypes I, II, and III aligned closest with Waitea circinata var. circinata, yet the colony morphology of $R$. oryzae genotypes I, II, and III match the description of W. circinata var. circinata, W. circinata var. oryzae, and $W$. circinata var. zeae, respectively, in the older literature (Gunnell 1986; Leiner and Carling 1994).

Pathogenicity and virulence of $\boldsymbol{R}$. solani, AG-I-like binucleate Rhizoctonia sp., and $\boldsymbol{R}$. oryzae. The tube assay was used to determine the ability of representative isolates of $R$. solani AG-8, AG-2-1, and AG-10; AG-I-like binucleate Rhizoctonia sp.; and $R$. oryzae genotypes I, II, and III to cause disease on wheat. All isolates caused damage to wheat roots (Table 4) that ranged from trace amounts of brown lesions or discoloration to serious root rotting, and slight to significant reductions in plant height. Isolates of AG-10, AG-I, AG-2-1, and R. oryzae genotype I produced only minor root damage (Table 4 ) characterized by browning of the roots, which is exemplified by the effect of AG-2-1 (Fig. 6A and C). In contrast, only isolates of AG-8 and $R$. oryzae genotypes II and III produced serious root disease (Table 4) and symptoms (spear tips, browning, and cortical collapse) typically associated with Rhizoctonia root rot and bare patch (Fig. 6B, D, and E; Fig. 7A to D). $R$. oryzae genotype II and III isolates were notable because they also caused significant stunting and distortion of seedlings (Fig. 7A and B). In addition, they often caused brown lesions on the coleoptiles. Only isolates of AG-8 and $R$. oryzae genotypes II and III significantly reduced plant height compared with the nontreated control (Table 4).

To insure that the symptoms observed were consistent across isolates, 20 isolates each of $R$. solani AG-8 and AG-2-1 (Table 3) were tested for ability to cause root disease on wheat. AG-8 isolates varied significantly in the severity of root disease but all caused symptoms typically associated with Rhizoctonia root rot and bare patch (Fig. 6B, D, and E). The ability of an isolate to produce these symptoms correlated perfectly with a positive PCR using AG-8 specific primers and AG-8 colony morphology on PDA. All AG-8 isolates were more virulent than AG-2-1 isolates on wheat (Table 3).

The tube assay also was used to compare the ability of isolates of AG-8, AG-2-1, and AG-10; AG-I-like binucleate Rhizoctonia sp.; and $R$. oryzae genotypes I, II, and III to cause disease on canola
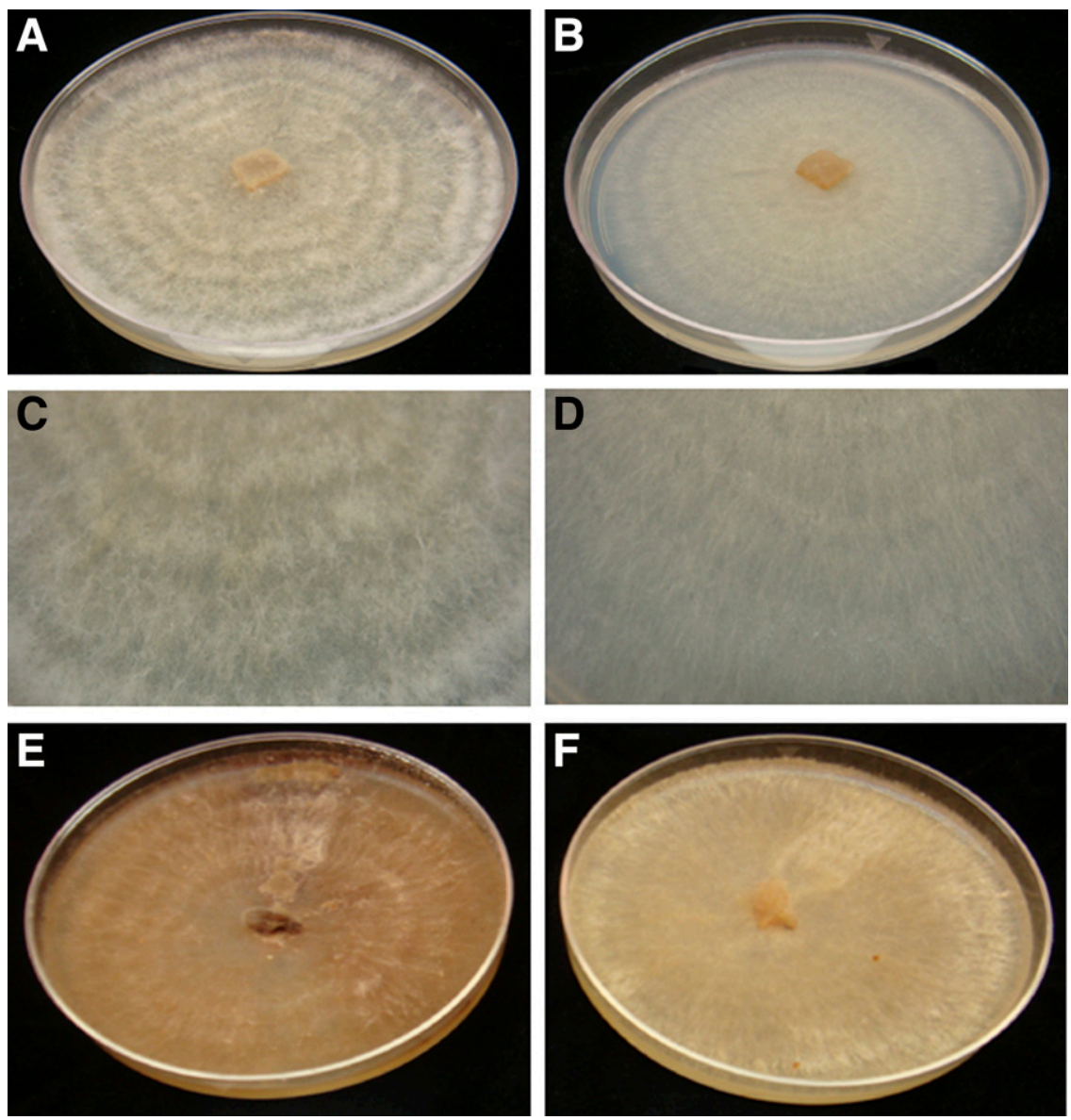

Fig. 3. Colony characteristics of Rhizoctonia solani $\mathbf{A}, \mathbf{C}$, and E, anastomosis group (AG)-2-1 and $\mathbf{B}, \mathbf{D}$, and F, AG-8 isolates on potato dextrose agar at 7 days (A, $\mathbf{B}, \mathbf{C}$, and $\mathbf{D}$ ) and 30 days (E and $\mathbf{F})$ after inoculation. AG-2-1 isolates produced prominent and defined concentric rings of radial growth, whereas those of AG-8 isolates were less prominent. AG-2-1 isolates were darker than AG-8 isolates at 30 days. 
(Table 5). All isolates caused some type of damage, seen primarily as a pre- or postemergence damping-off or stunting of the plant. On the basis of these measures of disease, the virulence among isolates differed significantly (Table 5). All three isolates of AG-2-1 killed canola by 4 weeks and they were significantly more virulent on canola than all other Rhizoctonia isolates tested (Table 5).

To further validate that these traits were consistent across isolates, the same 20 isolates each of AG- 8 and AG-2-1 tested on wheat (Table 3 ) were compared for ability to cause disease on canola
(Table 3). As in the previous experiments, all AG-2-1 isolates killed canola within 4 weeks and the isolates did not differ in virulence. In contrast, AG-8 isolates varied significantly in virulence as measured by postemergence damping-off, ability to kill canola, and plant height. No AG-8 isolate showed the same level of aggressiveness on canola as was shown by the AG-2-1 isolates. In all studies, the ability to rapidly kill canola correlated completely with a positive PCR reaction with AG-2-1 primers and the AG-2-1 colony morphology on PDA.

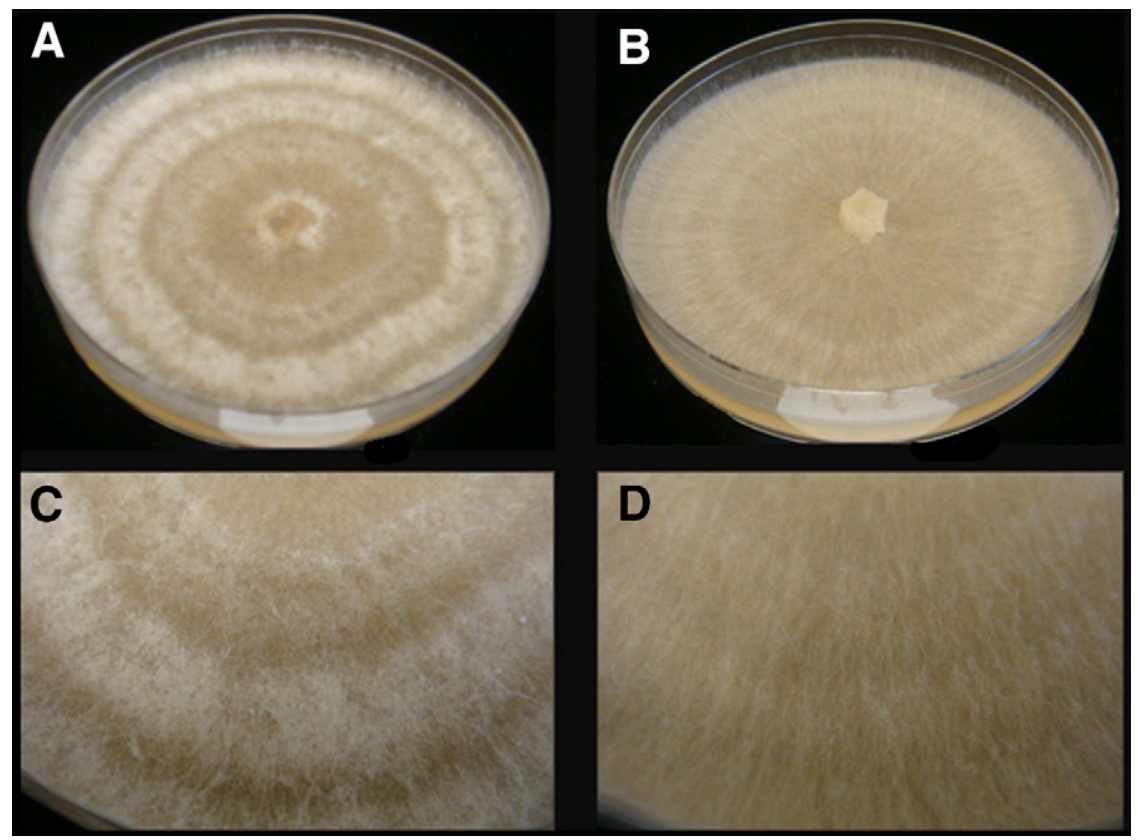

Fig. 4. Colony characteristics of isolates of $\mathbf{A}$ and $\mathbf{C}$, Rhizoctonia solani anastomosis group (AG)-10 and $\mathbf{B}$ and $\mathbf{D}$, AG-I-like binucleate Rhizoctonia sp. on potato dextrose agar at 7 days after inoculation. AG-10 isolates produced concentric rings of growth that were wide and had cottony, silky aerial mycelium. AG-I-like binucleate Rhizoctonia sp. isolates produced less defined concentric rings of growth and the mycelium had a moist appearance and produced submerged mycelium.

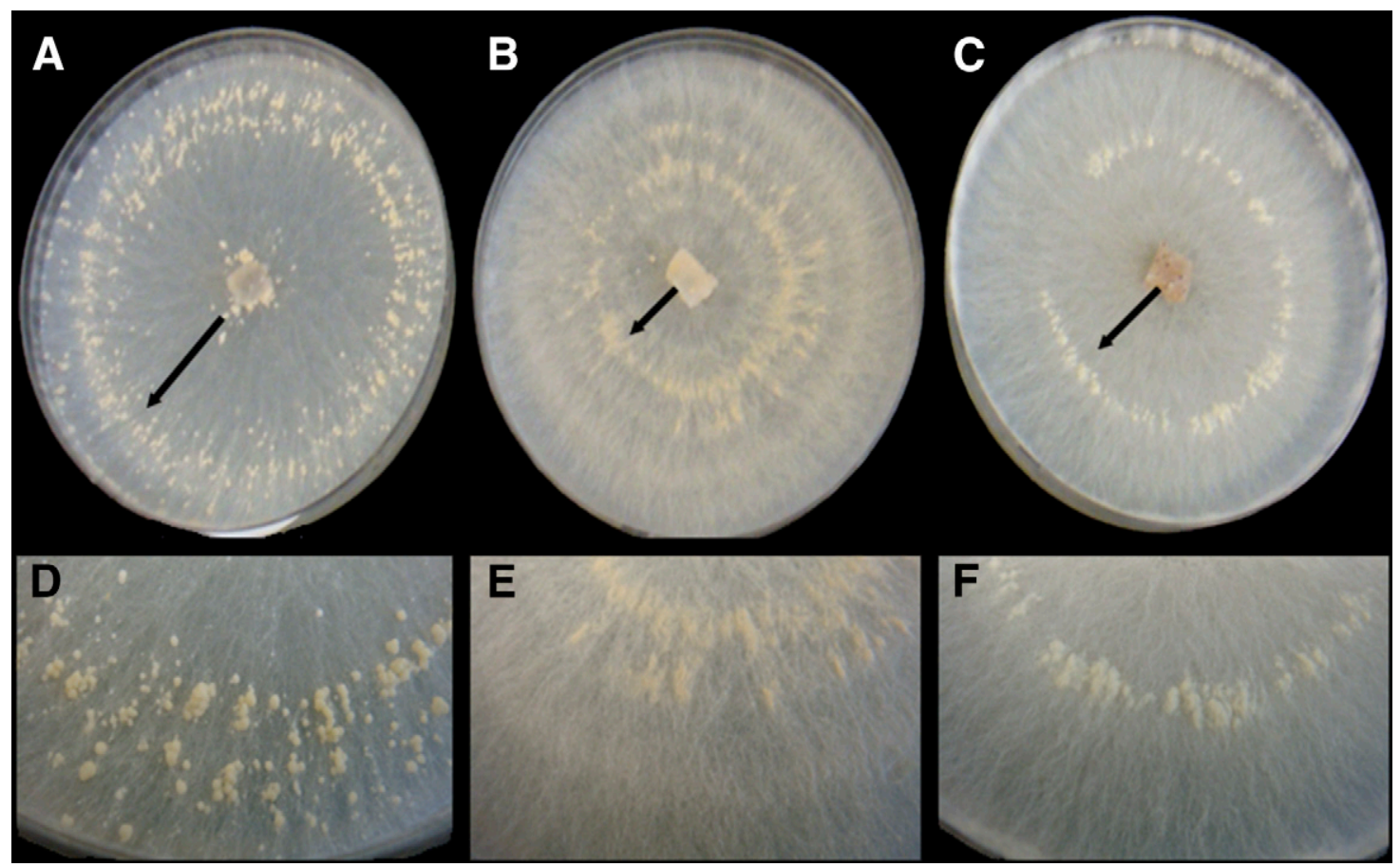

Fig. 5. Colony characteristics of Rhizoctonia oryzae genotypes A and D, I, B and E, II, and C and F, III isolates on potato dextrose agar at 7 days after inoculation. Members of all genotypes produced abundant sclerotia (compact masses of monilioid cells) at 7 days old. Genotype I sclerotia were orange to brown in color and globose in shape; genotype II sclerotia were orange to salmon in color and irregular in shape; and genotype III sclerotia were light brown to brown in color and regular in shape. Arrows indicate the different locations in the cultures where sclerotia formed. 
Geographic distribution of $R$. solani, AG-I-like binucleate Rhizoctonia sp., and $\boldsymbol{R}$. oryzae in Washington State. Rhizoctonia isolates (498 total) collected during three different surveys (2000 to 2009 [201 isolates], 2010 [117 isolates], and 2011 [180 isolates]) of

TABLE 4. Virulence of Rhizoctonia solani anastomosis groups (AGs), AG-Ilike binucleate Rhizoctonia sp., and R. oryzae on wheat ('Louise')

\begin{tabular}{|c|c|c|c|c|}
\hline Isolate $^{v}$ & AG or speciesw & Location $^{\mathrm{x}}$ & $\begin{array}{l}\text { Disease } \\
\text { ratingy }\end{array}$ & $\begin{array}{c}\text { Plant } \\
\text { height }(\mathrm{cm})^{\mathrm{z}}\end{array}$ \\
\hline Control & & & $0.0 \mathrm{~d}$ & $29.2 \mathrm{ab}$ \\
\hline AG-8 C-1 & AG-8 & Clyde & $5.2 \mathrm{a}$ & $24.8 \mathrm{c}$ \\
\hline T6S3-Rs11 & AG-8 & Cunningham & $5.3 \mathrm{a}$ & $25.0 \mathrm{c}$ \\
\hline T11S2-Rs11 & AG-8 & Odessa & $5.1 \mathrm{a}$ & $25.4 \mathrm{c}$ \\
\hline Rh080741(181) & AG-10 & Pullman & $0.6 \mathrm{bcd}$ & $28.9 \mathrm{ab}$ \\
\hline Rh080322 (154) & AG-10 & Garfield & $0.6 \mathrm{bcd}$ & $29.3 \mathrm{ab}$ \\
\hline Rh060609 (145) & AG-I & Ritzville & $0.3 \mathrm{bcd}$ & $28.2 \mathrm{ab}$ \\
\hline Rh100702 (63) & AG-I & Ritzville & $0.2 \mathrm{~cd}$ & $28.1 \mathrm{~b}$ \\
\hline $\mathrm{Rh} 0810015$ & AG-2-1 & Walla-Walla & $1.1 \mathrm{~b}$ & $29.0 \mathrm{ab}$ \\
\hline T5S1-Rs10 & AG-2-1 & Marcellus & $1.0 \mathrm{bc}$ & $28.0 \mathrm{~b}$ \\
\hline T67S1-Rs11 & AG-2-1 & Pullman & $0.8 \mathrm{bc}$ & $28.2 \mathrm{ab}$ \\
\hline T87S1-Ro10 & RoGI & Colfax & $0.6 \mathrm{bcd}$ & $28.9 \mathrm{ab}$ \\
\hline T70S1-Ro11 & RoGI & Grinnell & $0.4 \mathrm{bcd}$ & $29.9 \mathrm{a}$ \\
\hline T21S6-Ro11 & RoGII & Chard & $5.5 \mathrm{a}$ & $19.0 \mathrm{e}$ \\
\hline T87S2-Ro10 & RoGII & Colfax & $4.4 \mathrm{a}$ & $23.9 \mathrm{c}$ \\
\hline T39S3-Ro10 & RoGIII & St. John & $5.2 \mathrm{a}$ & $21.7 \mathrm{~d}$ \\
\hline T79S3-Ro11 & RoGIII & North Pine & $5.1 \mathrm{a}$ & $20.2 \mathrm{de}$ \\
\hline
\end{tabular}

${ }^{v}$ Isolates were collected using the toothpick assay (Paulitz and Schroeder 2005).

${ }^{\mathrm{w}} R$. solani $\mathrm{AG}$, AG-I-like binucleate Rhizoctonia $\mathrm{sp}$., and $R$. oryzae group (RoG) I, II, and III.

$\mathrm{x}$ Isolates are from commercial fields or experimental plots near these Washington cities.

y Disease was rated on a scale of 0 to 8 : $0=$ no disease and $8=$ plant dead or nearly so at 4 weeks after planting. Means followed by the same letter in the same column are not significantly different at $P=0.05$ according to the Kruskal-Wallis test.

${ }^{\mathrm{z}}$ Height of five plants from each of three replicates was measured at 4 weeks after planting. Means in the same column followed by the same letter are not significantly different at $P=0.05$ according to Fisher's protected least significant difference test. fields in the Washington State were identified by PCR with the primers described in Table 1 or by sequencing of the ITS region (AG-3, AG-4, and AG-11) when specific primers were not available. Ten different AGs or species of Rhizoctonia were found in these collections. $R$. solani AG-2-1, AG-8, AG-10, AG-3, AG-4, and AG-11 comprised 157 (32\%), 70 (14\%), 21 (4\%), 20 (4\%), 1 $(0.2 \%)$, and $1(0.2 \%)$, respectively, of the total isolates. AG-I-like binucleate Rhizoctonia sp. comprised 44 (9\%) of the total; and 53 (11\%), $80(16 \%)$, and $51(10 \%)$ were identified as $R$. oryzae genotypes I, II, and III, respectively.

Figures 8, 9, and 10 show the geographic distribution of Rhizoctonia AGs and species belonging to the 2000 to 2009, 2010, and 2011 collections, respectively. Overall, the frequency of isolation of some AGs or species differed substantially among collections. Some Rhizoctonia were cosmopolitan in their distribution and others were endemic to certain agronomic zones. For example, the most frequently and consistently isolated $R$. solani was AG-2-1 $(29,39$, and $29 \%$ of the 2000 to 2009,2010 , and 2011 collections, respectively) and it was distributed across all six agronomic zones in the Inland PNW. $R$. oryzae also was cosmopolitan (37\% of all isolates) and found in all six agronomic zones, but isolates of the three genotypes were not equally distributed. Genotype II isolates were recovered from five of the six zones and were the most commonly recovered (Table 6, Figs. 8, 9, and 10). Genotype III isolates also were consistently found in all six agronomic zones. Genotype I isolates were found in only five zones but in contrast with isolates of genotypes II and III, they occurred inconsistently among the collections; they comprised 0,21 , and $16 \%$ of the isolates in the 2000 to 2009, 2010, and 2011 collections and were most abundant in zones with precipitation $>400 \mathrm{~mm}$. In total, AG-2-1 and $R$. oryzae occurred under low (150 to $300 \mathrm{~mm}$ ), intermediate (300 to 450$)$, and higher $(>450 \mathrm{~mm})$ precipitation.

$R$. solani AG-8 also was isolated from all six agronomic zones, but it was most common in zones with $<400 \mathrm{~mm}$ of precipitation. However, the frequency of isolation of AG-8 was very inconsistent;

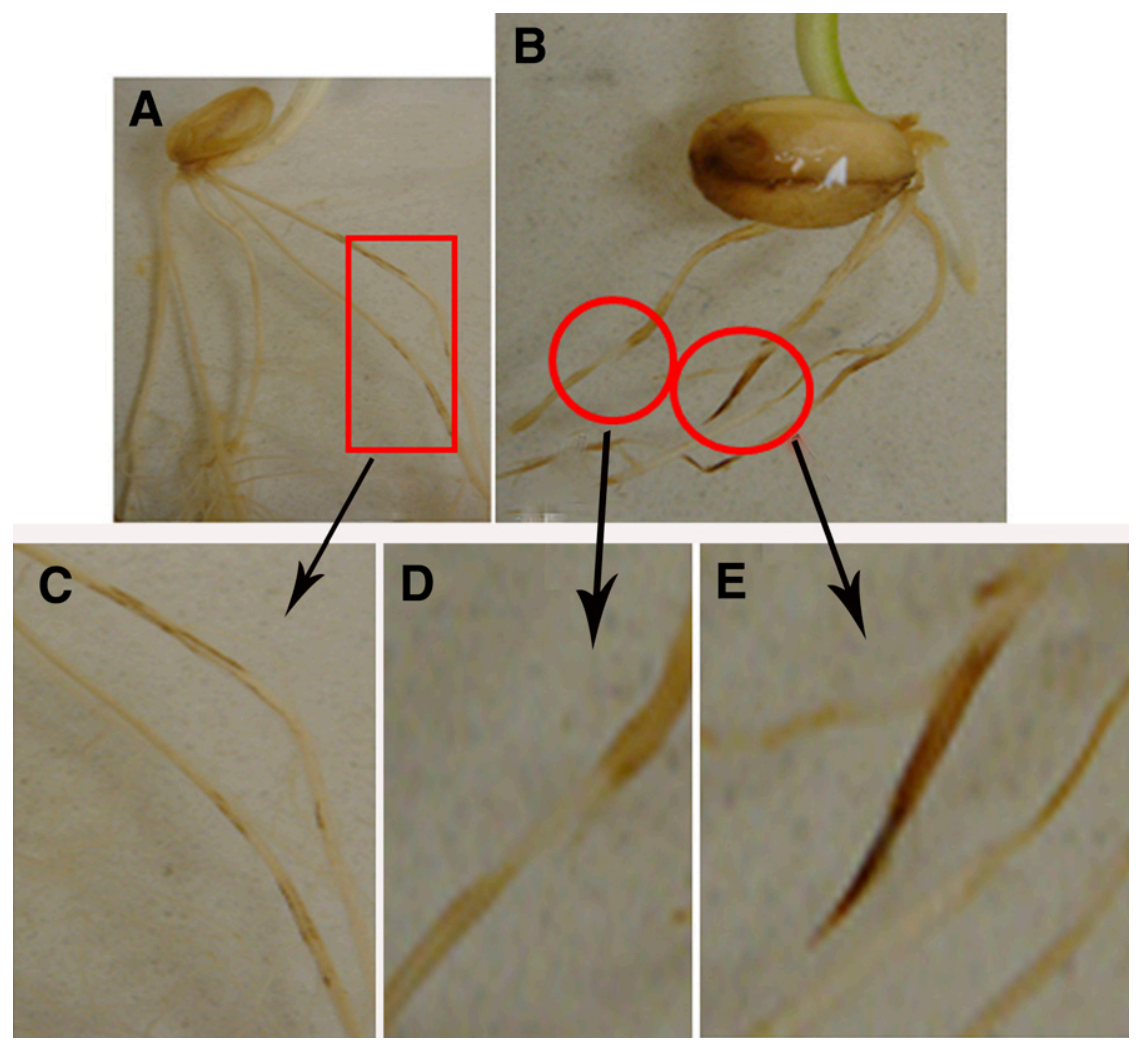

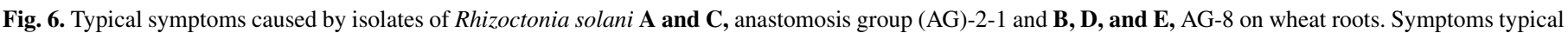

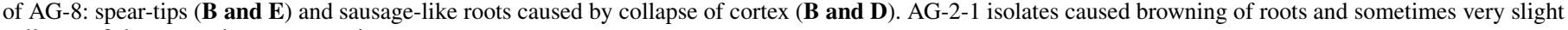
collapse of the cortex but no spear tips. 
it comprised 8, 6, and $26 \%$ of the isolates in the 2000 to 2009,2010 , and 2011 collections, respectively. Especially notable was the striking difference in the number of isolates of AG-8 recovered from near Ritzville and Lind, WA in 2010 and 2011 because in both years many of the same fields were sampled. AG-I-like binucleate Rhizoctonia sp. isolates (Ceratobasidium-like) also were widespread and present in five agronomic zones, but their frequency of occurrence was inconsistent. For example, in the 2000 to 2009 collection, AG-I comprised $19 \%$ of the total isolates but in the 2010 and 2011 collections they comprised $0 \%$ and $3 \%$ of the isolates, respectively. AG-10 isolates were found in four agronomic zones but primarily in those where the precipitation was $>400 \mathrm{~mm}$. The occurrence of AG-10 was also inconsistent, comprising 9, 1, and $1 \%$ of the isolates in the 2000 to 2009,2010 , and 2011 collections, respectively. AG-3 isolates were cosmopolitan and found in all six zones but they comprised only $4 \%$ of the total isolates in the three collections. $R$. solani AG-4 and AG-11 isolates each represented only $0.2 \%$ of the total of the three collections.

\section{DISCUSSION}

The results of our study and that of Okubara et al. (2014) paint a much more complex picture of the ecology and distribution of
Rhizoctonia AGs/species that can infect crops produced in cerealbase cropping systems of the Inland PNW than was previously thought to occur. The fields sampled are part of the largest contiguous cropping system in the western United States and in this agroecosystem wheat is the dominant crop grown. Rhizoctonia root rot and bare patch are important diseases of direct-seeded (no-till) wheat and barley in the Inland PNW and have increased in prevalence with the reduction in tillage needed to control the severe wind and water erosion that occurs annually in this agro-ecosystem. Despite over 25 years of research, major gaps remain in our fundamental understanding of the epidemiology of Rhizoctonia root rot and bare patch and the biology and ecology of the causal agents, $R$. solani AG-8 and $R$. oryzae. Multiple Rhizoctonia AGs/ species can simultaneously colonize cereal roots or "bare patches" in the field, making it challenging to isolate and identify the causal agents, especially for researchers and diagnosticians who have little or no experience with the disease. AG- 8 can be particularly difficult to isolate and identify. Our findings greatly simplify the process of identifying AG-8 isolates even if real-time PCR is not available. Using a broad collection of Rhizoctonia isolates and building on the findings of Okubara et al. (2008) and Paulitz and Schroeder (2005), we demonstrated for the first time that isolates of AG- 8 can be clearly distinguished from those of other groups collected in the
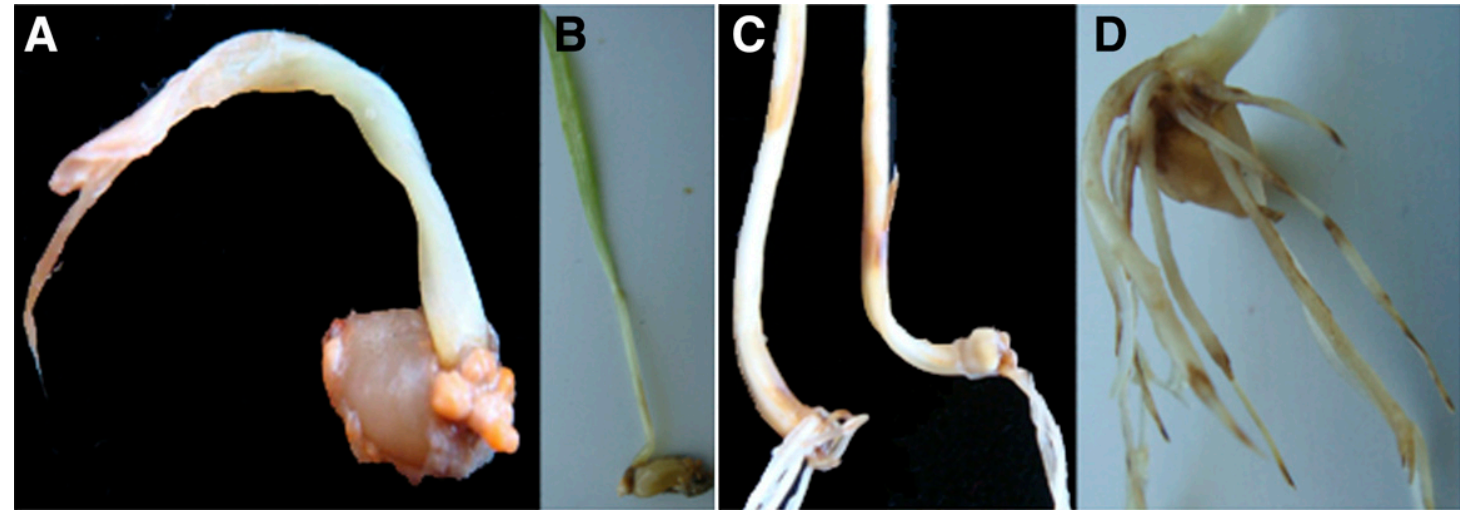

Fig. 7. Typical symptoms of Rhizoctonia root rot caused by Rhizoctonia oryzae genotypes II and III: A and B, extreme stunting, $\mathbf{C}$, brown lesions on coleoptiles, and $\mathbf{D}$, spear-tips and collapse of root cortex. Note the sclerotia formed at the base of the coleoptile (A).

TABLE 5. Pathogenicity or virulence of Rhizoctonia solani anastomosis groups (AGs), AG-I-like binucleate Rhizoctonia sp., and R. oryzae on canola TR8

\begin{tabular}{|c|c|c|c|c|c|}
\hline Isolates $^{\mathrm{u}}$ & $\mathrm{AG}$ or species $^{\mathrm{v}}$ & Location $^{\mathrm{w}}$ & Postemergence damping-off $(\%)^{\mathrm{x}}$ & Surviving plants $(\%)^{\mathrm{y}}$ & Plant height $(\mathrm{cm})^{\mathrm{z}}$ \\
\hline Control & & & $0 \mathrm{~b}$ & $100 \mathrm{a}$ & $7.5 \mathrm{a}$ \\
\hline AG-8 C-1 & AG-8 & Clyde & $0 \mathrm{~b}$ & $33 \mathrm{def}$ & $5.9 \mathrm{f}$ \\
\hline T6S3-Rs11 & AG-8 & Cunningham & $1 \mathrm{~b}$ & $24 \mathrm{ef}$ & $5.8 \mathrm{f}$ \\
\hline Rh080741(181) & AG-10 & Pullman & $0 \mathrm{~b}$ & $17 \mathrm{fg}$ & $6.2 \mathrm{ef}$ \\
\hline $\mathrm{Rh} 080322$ (154) & AG-10 & Garfield & $1 \mathrm{~b}$ & 41 cde & $6.8 \mathrm{bcd}$ \\
\hline Rh060609 (145) & AG-I & Ritzville & $0 \mathrm{~b}$ & $100 \mathrm{a}$ & $7.2 \mathrm{ab}$ \\
\hline Rh100702 (63) & AG-I & Ritzville & $1 \mathrm{~b}$ & $48 \mathrm{~cd}$ & $7.4 \mathrm{ab}$ \\
\hline T67S1-Rs11 & AG-2-1 & Pullman & $30 \mathrm{a}$ & $0 \mathrm{~g}$ & $0.0 \mathrm{~g}$ \\
\hline T87S1-Ro10 & RoGI & Colfax & $1 \mathrm{~b}$ & $81 \mathrm{ab}$ & $7.1 \mathrm{abc}$ \\
\hline T70S1-Ro11 & RoGI & Grinnell & $0 \mathrm{~b}$ & $74 \mathrm{~b}$ & $6.8 \mathrm{bcd}$ \\
\hline T21S6-Ro11 & RoGII & Chard & $1 \mathrm{~b}$ & $36 \mathrm{cde}$ & $7.1 \mathrm{abc}$ \\
\hline T87S2-Ro10 & RoGII & Colfax & $0 \mathrm{~b}$ & $55 \mathrm{c}$ & $7.2 \mathrm{ab}$ \\
\hline T39S3-Ro10 & RoGIII & St. John & $1 \mathrm{~b}$ & 26 ef & $7.0 \mathrm{abc}$ \\
\hline T79S3-Ro11 & RoGIII & North Pine & $0 \mathrm{~b}$ & 29 ef & 6.6 cde \\
\hline
\end{tabular}

u Isolates were collected using the toothpick assay (Paulitz and Schroeder 2005).

${ }^{v} R$. solani AG, AG-I-like binucleate Rhizoctonia sp., and $R$. oryzae group (RoG) I, II, and III.

w Isolates are from commercial fields or experimental plots near these Washington cities.

x Number of plants damping-off after emergence was determined at 4 weeks after planting. Means in the same column followed by the same letter are not significantly different at $P=0.05$ according to Fisher's protected least significant difference (LSD) test.

y Number of plants surviving was determined at 4 weeks after planting. Means in the same column followed by the same letter are not significantly different at $P=0.05$ according to Fisher's protected LSD test.

${ }^{\mathrm{z}}$ Plant height of five plants from each of three replicates was measured at 4 weeks after planting. Means in the same column followed by the same letter are not significantly different at $P=0.05$ according to Fisher's protected LSD test. 
Inland PNW on the basis of three parameters: colony morphology on PDA after 7 days of growth, conventional PCR product after amplification with primers Rs8F/Rs8R (amplifies a 327-bp fragment), or production of classical root rot symptoms in a tube assay.
All AG-8 isolates collected over a 12-year period and representing the largest collection of AG-8 in the United States were identical in these three traits, giving confidence that any one of them can be used to identify AG-8 isolates. Although AG-8 isolates differed in virulence,

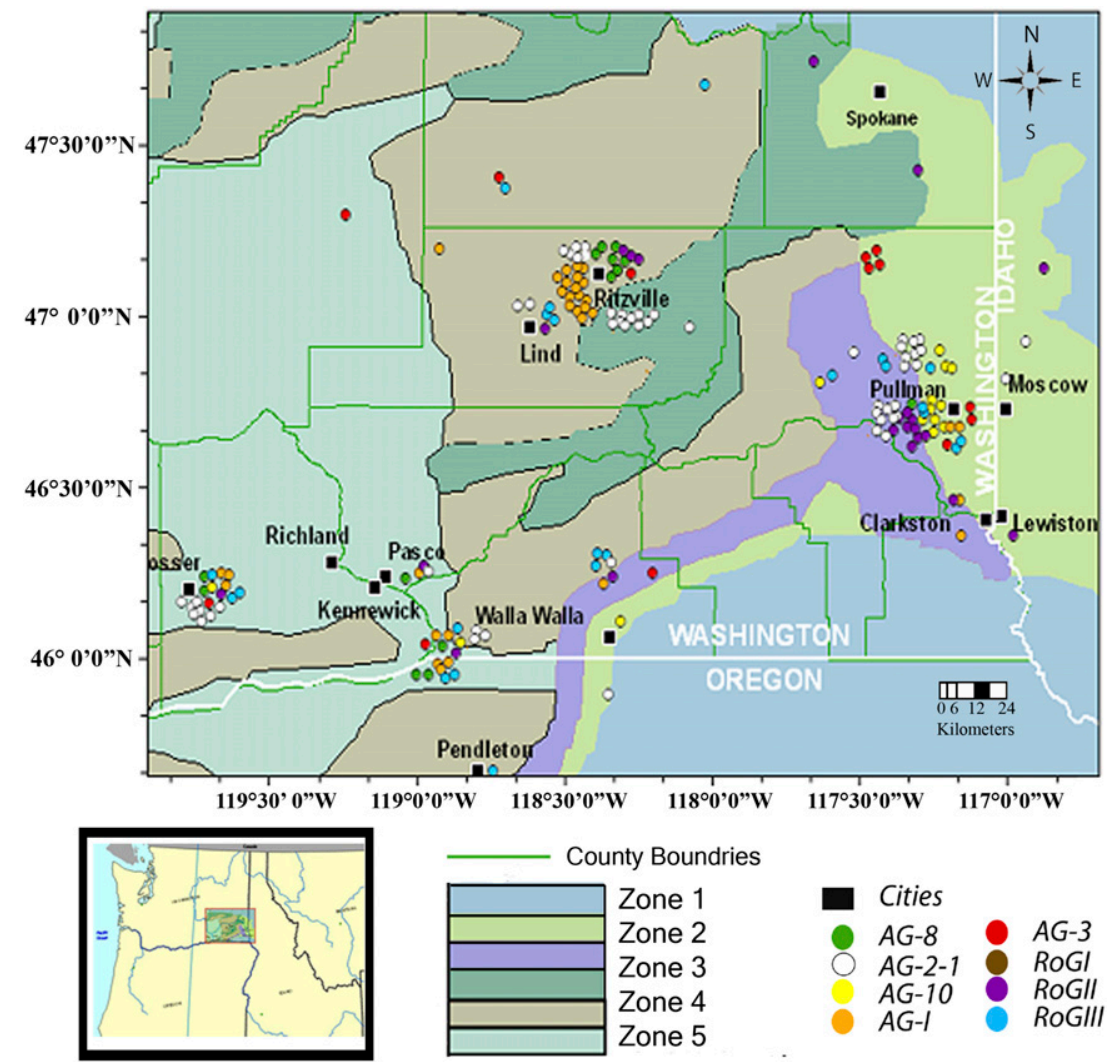

Fig. 8. Geographic distribution of Rhizoctonia anastomosis groups (AGs) and species collected primarily in Washington state from cereal-based cropping systems by T. Paulitz from 2000 to 2009. The colored circles designate the locations where Rhizoctonia isolates were collected and black squares indicate nearby cities in Washington, Oregon, and Idaho. The colored areas indicate agronomic zones which are described in Table 2.

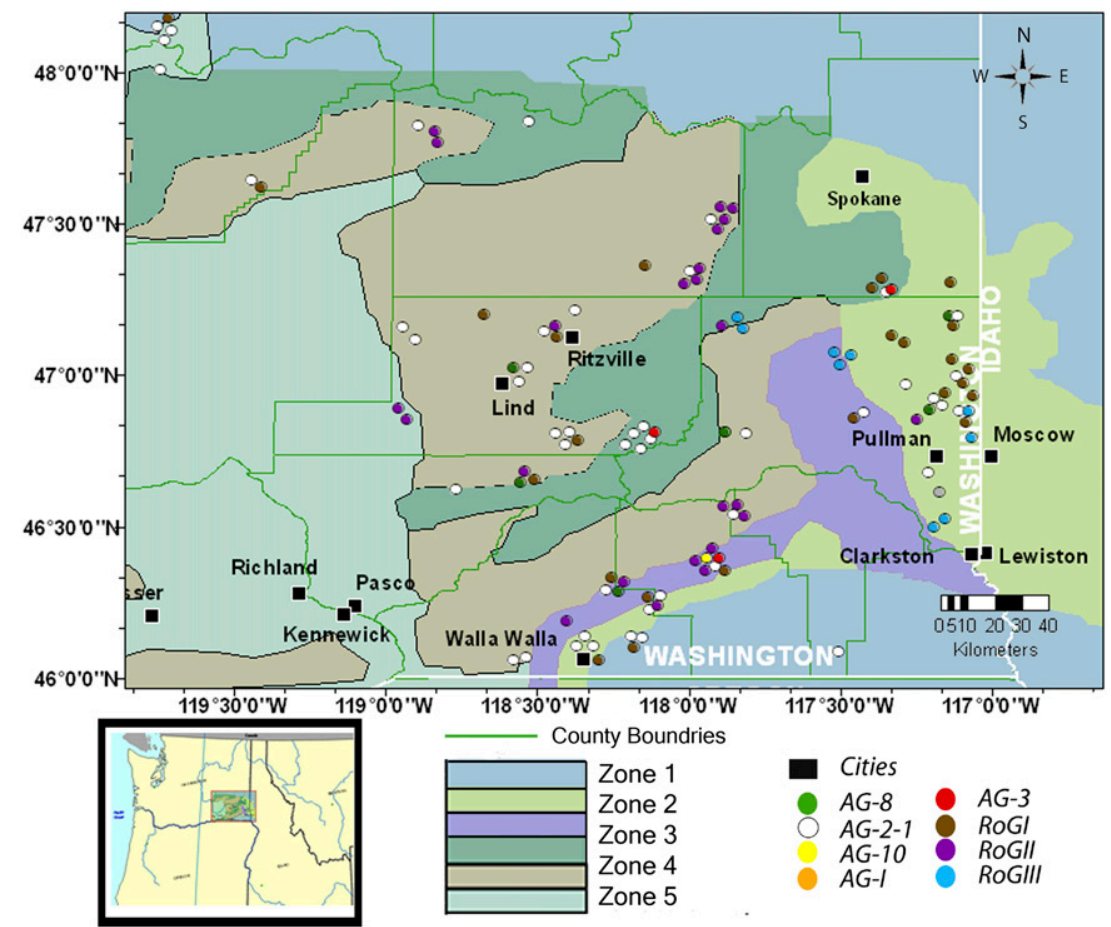

Fig. 9. Geographic distribution of Rhizoctonia anastomosis groups (AGs) and species collected primarily in Washington state from cereal-based cropping systems during this study in 2010. The colored circles designate the location where Rhizoctonia isolates were collected and black squares indicate nearby cities in Washington and Idaho. The colored areas indicate agronomic zones which are described in Table 2. 
they all caused classical symptoms: spear tips and collapse of the root cortex. Only isolates of $R$. oryzae genotypes II and III also caused symptoms on wheat that resembled those of AG-8, but $R$. oryzae isolates are easily distinguished from AG-8 isolates.

Our results also showed that isolates of AG-2-1, the most common $R$. solani in cereal-based production systems in Washington and a devastating pathogen of canola (Anderson 1977; Carling and Summer 1992; Paulitz et al. 2006) often confused with AG-8, could clearly be distinguished from other Rhizoctonia isolates based upon colony morphology, PCR product amplified with primers Rs2.1F/Rs2.1R (produces a 441-bp fragment), or ability to cause postemergence damping-off on canola in the tube assay. Only AG-2-1 isolates killed all canola seedlings by 4 weeks in the tube assay. We think that many isolates from wheat roots previously considered to be AG- 8 based on colony characteristics were indeed AG-2-1.

The tube assay used to determine the virulence of the Rhizoctonia isolates was based on an assay described by Kwak et al. (2009) to test Gaeumannomyces graminis var. tritici or Phialophora spp. (Kwak et al. 2010) on wheat. They used agar plugs colonized by the test fungus as inoculum in a column of sterile vermiculite. Surprisingly, with this assay most AG-8 isolates caused only very mild disease on wheat and often failed to cause typical root rot symptoms. In the current study, the addition of a layer of pasteurized Quincy virgin soil to the tube assay alleviated this problem and all AG- 8 isolates then produced classical symptoms. In addition, preliminary studies (not shown) demonstrated that three 5-mm-diameter plugs cut from a 7-day-old PDA culture was the ideal amount of inoculum to differentiate the AGs/species on the basis of disease ratings of wheat roots and damping-off of canola in the tube assay. A variety of other assays have been used to test the virulence of Rhizoctonia spp. against wheat and barley but those assays typically have used autoclaved oats, millet seed or rye grass seed colonized by an isolate as the inoculum (Mazzola 1997; Okubara and Jones 2011; Ogoshi et al. 1990; Schroeder and Paulitz 2008; Smith et al. 2003a, b). Those inocula take weeks to prepare and are tedious to use when a large number of isolates need to be tested; also the inoculum potential can vary depending on the age of the inoculum and how it was stored. The tube assay developed in this study is simple, rapid and highly reproducible.

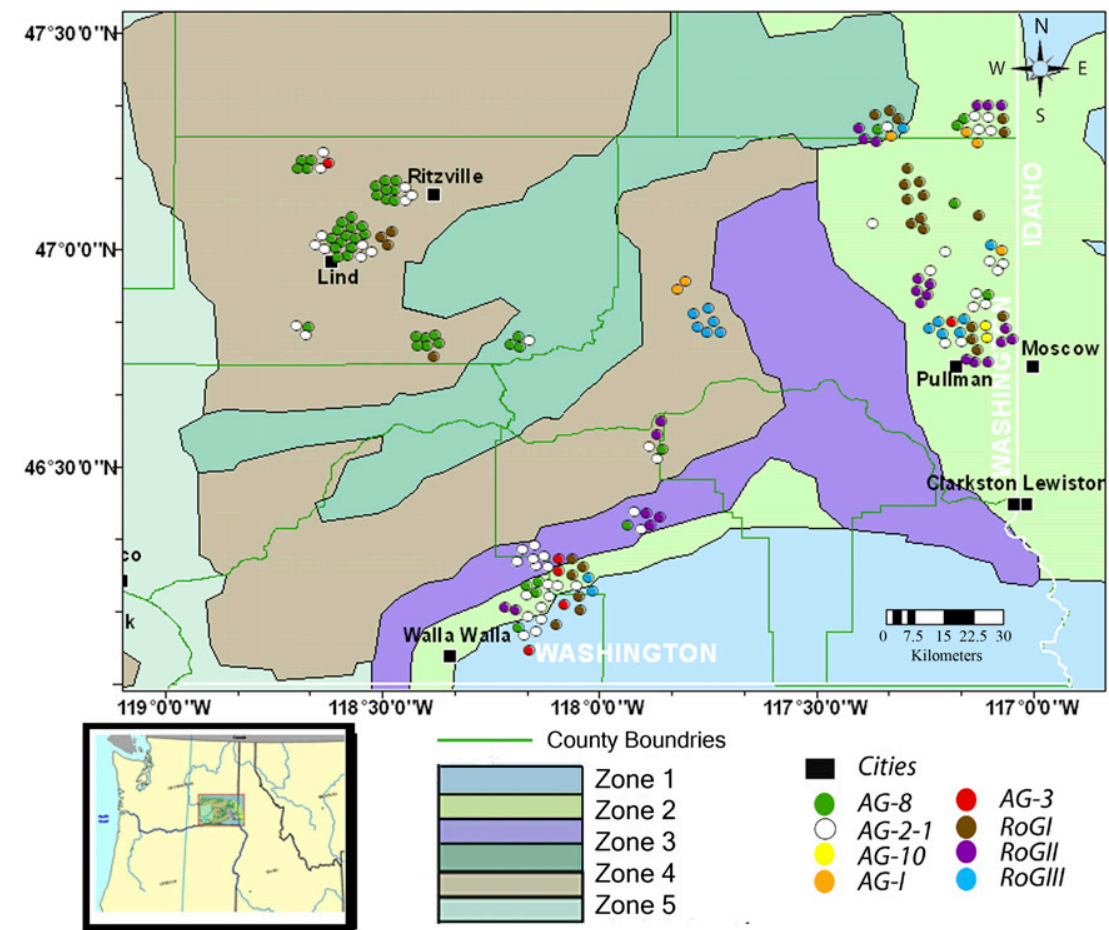

Fig. 10. Geographic distribution of Rhizoctonia anastomosis groups (AGs) and species collected primarily in Washington state from cereal-based cropping systems during this study in 2011. The colored circles designate the location where Rhizoctonia isolates were collected and black squares indicate nearby cities in Washington and Idaho. The colored areas indicate agronomic zones which are described in Table 2.

TABLE 6. Anastomosis group (AG) and species of Rhizoctonia isolates from cereal-based cropping systems in Washington State

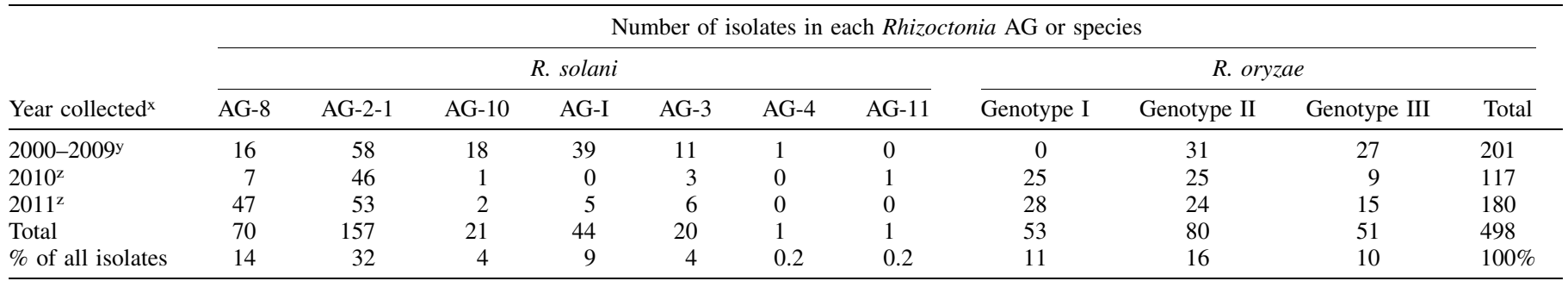

x Year isolates were collected. The collection of T. Paulitz (USDA-ARS, Pullman, WA) was built from 2000 to 2009 and new isolates were added as they were collected throughout the growing season.

y Isolates were randomly selected from this collection.

z All isolates were collected between mid-May and mid-July. 
Our study identified the biogeographic distribution of Rhizoctonia AGs/species in cereal-based cropping systems of Washington State by analyzing 498 isolates collected between 2000 and 2011 . These isolates were part of three separate collections: isolates collected by T. Paulitz from 2000 to 2009 , and isolates collected in 2010 and 2011 as part of this current study. Ten different AGs/ species of Rhizoctonia were identified including $R$. solani AGs 2-1, 3, 4, 8, 10, and 11; AG-I-like binucleate Rhizoctonia sp.; and $R$. oryzae genotypes I, II, and III, and their location of origin was plotted on a map via GPS coordinates (Figs. 8, 9, and 10). AG-2-1, known for its ability to cause damping-off and root rot of brassicas (especially canola) (Anderson 1977; Carling and Summer 1992; Khangura et al. 1999; Paulitz et al. 2006), was the most frequently isolated $R$. solani. AG-2-1 was cosmopolitan in its distribution, being present in all six agronomic zones and thus apparently well adapted to growing on cereals even though it causes only minor damage to their roots. The fact that it comprised 29, 39, and $29 \%$ of the isolates in the collections from 2000 to 2009, 2010, and 2011 suggests that the methods of collecting the isolates were consistent throughout the years. This AG was also the most commonly isolated in surveys of wheat soils in the United States (K. L. Schroeder, K. Shetty, and T. C. Paulitz, unpublished data) and from Canada (Broders et al. 2014).

$R$. oryzae was also cosmopolitan in its distribution and the most frequently isolated Rhizoctonia species, with the three genotypes comprising $37 \%$ of all of the Rhizoctonia isolates tested in the three collections. Ogoshi et al. (1990), who originally described the importance of $R$. oryzae to the etiology of Rhizoctonia root rot, reported that this fungus comprised $45 \%$ of the isolates collected from 45 PNW fields. In addition, Paulitz et al. (2002) found in a 2001 survey of eastern Washington that $R$. oryzae often comprised more than $50 \%$ (and sometimes 100\%) of the Rhizoctonia species isolated, and in a more limited collection, Okubara et al. (2014) detected genotype III DNA in about half of plots screened across annual precipitation zones ranging from less than $305 \mathrm{~mm}$ to greater than $508 \mathrm{~mm}$ over a 3-year survey period. The former two studies recovered Rhizoctonia isolates from both soil and roots but root isolations are known to favor the selection of $R$. oryzae. We think that the frequency of $R$. oryzae found in this current study, which utilized the toothpick assay (Paulitz and Schroeder 2005), more accurately reflects the abundance of the three genotypes of $R$. oryzae in Washington State fields.

$R$. solani AG-8 was isolated from all six agronomic zones, yet most isolates were collected from regions that received less than $400 \mathrm{~mm}$ of annual precipitation. This result is consistent with those of Okubara et al. (2014), who detected higher levels of $R$. solani AG-8 DNA in soils from fields and variety test plots receiving comparatively little $(<305 \mathrm{~mm})$ annual precipitation (RitzvilleConnell area and the area around Dayton-Walla Walla). However, in contrast to the results of Okubara et al. (2014), who found $R$. solani AG-8 at the detection limit in some of the higher precipitation areas of eastern Washington, we recovered very few $R$. solani AG-8 isolates from those areas. It may be that the natural populations were so low that we could not isolate them with our traditional plating techniques, or alternatively, that Okubara et al. (2014) may have detected false positives, given that the PCR primers in that work also can weakly amplify DNA from $R$. solani AG-2.1, which is common in those areas on broadleaf rotation crops. Regardless, the question remains as to why classic bare patch symptoms and high frequencies of $R$. solani AG-8 appear primarily in fields in the low precipitation zone. It may be that the sandy soils present in those areas are more conducive for the spread of the fungus as a patch, since Rhizoctonia spp. may favor larger soil pores to spread (Gill et al. 2000; Otten et al. 2004). In any case, over the entire survey area $R$. solani AG-8 comprised 8, 6, and $26 \%$ of the Rhizoctonia isolates in the 2000 to 2009, 2010, and 2011 collections, respectively. Notable was the difference in the number of isolates of AG-8 collected from the Ritzville and Lind, WA areas in 2010 and 2011
(Figs. 9 and 10) because in both years many of the same fields were sampled. The number of hectares of wheat grown in the Inland PNW has remained constant for many years and the amount of wheat grown with reduced tillage is increasing; thus availability of a host and suitable conditions for disease are probably not factors in this phenomenon of inconsistent isolation.

AG-I-like binucleate Rhizoctonia sp. was the fourth most abundant Rhizoctonia species found in the three collections. It was present in five agronomic zones but its occurrence was inconsistent, comprising 39, 0, and 5\% of the isolates in 2000 to 2009, 2010, and 2011, respectively. AG-I is known as both a pathogen of strawberry roots (Martin 1988) and as a biocontrol agent that protects against other diseases caused by Rhizoctonia (Jabaji-Hare et al. 1999). However, AG-I also has been shown to be pathogenic on canola, chickpea, pea, and lentil, but not wheat or barley (Schroeder and Paulitz 2012b). The wide distribution of AG-I-like binucleate Rhizoctonia sp. isolates in Inland PNW fields suggests that they could play a role in limiting the distribution or virulence of Rhizoctonia root rot and bare patch. D. M. Weller (unpublished data) found that binucleate Rhizoctonia (of unknown AG affiliation) isolated from wheat and barley roots controlled root rot in greenhouse experiments when co-inoculated with AG-8 isolate C- 1 .

In the current study, AG-10 isolates were found in four agronomic zones but primarily where the precipitation was greater than $400 \mathrm{~mm}$. The frequency of isolation of AG-10 was rather inconsistent, comprising 9\% of the isolates in the 2000 to 2009 collection but only $1 \%$ in both of the 2010 and 2011 collections. Isolates of AG-10 are principally considered to be saprophytic (Carling and Sumner 1992) and not pathogenic on a wide host range (Gonzalez Garcia et al. 2006; MacNish et al. 1995). However, recently Schroeder and Paulitz (2012a) reported that AG-10 also caused root rot on canola in Washington State. In the current study, AG-10 caused damping-off of a significant number of canola plants in the tube assay and also a noticeable browning of wheat roots.

Of the less frequently recovered isolates in our collections, $R$. solani AG-3 is well known as a pathogen of crops in Solanaceae such as eggplant, potatoes, tomato, and tobacco (Gonzalez Garcia et al. 2006; Carling and Leiner 1990) but it has not been reported to be pathogenic to wheat and barley (Ogoshi et al. 1990). We found AG-3 isolates in all six zones but they comprised only $4 \%$ of our total isolates. Potato, a host for AG-3, is commonly grown in rotation with wheat under irrigation in the low precipitation zone. $R$. solani AG-4 and AG-11 isolates each represented only $0.2 \%$ of the total of the three collections and it is difficult to speculate on their significance in cereal-based cropping systems. AG-4 can cause damping-off of seeds and seedlings, root and crown rots, root and stem cankers, and stem blight on a very wide range of hosts worldwide (Anderson 1977; Carling and Sumner 1992; D' aes et al. 2011; Vincelli and Herr 1992), but it generally is not pathogenic or causes only slight discoloration of the roots of wheat and barley (Ogoshi et al. 1990). R. solani AG-11 can cause severe hypocotyl rot and damping-off of lupins (Sweetingham et al. 1986) and coleoptile rot on wheat (Carling et al. 1994; Demirci 1998; Sweetingham et al. 1986). It should be noted that to our knowledge this is the first time that an AG-11 has been isolated from a cereal-based cropping system in the Inland PNW.

Rhizoctonia root rot and bare patch are perhaps the least understood of all of the root and crown rots and damping-off diseases of wheat and barley caused by soilborne fungal pathogens. One puzzling characteristic of these diseases is that they are easily controlled by a single tillage operation (Pumphrey et al. 1987; Rovira 1986; Schroeder and Paulitz 2006; Smiley et al. 1996; Weller et al. 1986). This study showed that $R$. solani AG- 8 and $R$. oryzae are found throughout Washington State, yet root rot and bare patch were not detected there until 1984 (Weller et al. 1986), a time when cultivation practices began to move away from conventional tillage to reduced or conservation tillage. Whether the control of root rot by tillage is due to a reduction in the inoculum potential of AG-8 and 
$R$. oryzae resulting from the break-up of the mycelial network that can develop under no-till conditions and/or a change in soil structure and environment is yet to be determined (Schroeder and Paulitz 2008). A second puzzling characteristic of these diseases is the recent report (http://www.plantmanagementnetwork.org/pub/php/ news/2011/RhizoctoniaRegions/) from a Syngenta-sponsored study by K. L. Schroeder and T. Paulitz that AG-8 appears to be confined to the PNW. If not endemic there, was the pathogen introduced, probably from Australia, at some time in the past? The agricultural exchanges between Australia and the PNW have been extensive during the last several decades, and a genetic comparison of the Australian and Washington State AG-8 isolates is certainly warranted given this recent finding. On the other hand, the Syngentasponsored survey may not have been intensive or extensive enough to find AG- 8 outside of the PNW. Finally, perhaps the most puzzling characteristic of Rhizoctonia root rot and bare patch is that historically, AG-8 has been difficult to isolate from soil and even more so from diseased tissue, especially older diseased roots (Harris and Moen 1985; Paulitz and Schroeder 2005; Samuel and Garrett 1932; D. M. Weller, unpublished data). For example, in 1937, Hynes (1937) in Australia wrote the following about Rhizoctonia root rot: "The results were disappointing and show how difficult it is to isolate the pathogen in pure culture from roots severely attacked." Because of the difficulty of isolating AG-8, Harris and Moen (1985) questioned the role of AG-8 in root rot and suggested that other soilborne fungi may be as important or more important in disease development. D. M. Weller (unpublished data and personal communication) isolated AG-8 strain C-1 from a diseased barley root from Clyde, WA in 1984 but to get that single isolate it took dozens of attempts from diseased roots. The inconsistent frequency at which AG-8 isolates are found in the three Rhizoctonia collections also speaks to difficulty in isolating AG-8. This difficulty, and the confusion due to isolates of other Rhizoctonia AGs/species co-inhabiting the lesions, may be reasons why strain C-1 has been the "AG-8 isolate of choice" for most studies of root rot and bare patch in the PNW for the past 25 years (Mazzola 1997; Mazzola et al. 1996; Okubara and Jones 2011; Okubara et al. 2008, 2009; Paulitz and Schroeder 2005; Smith et al. 2003a, b). Strain $\mathrm{C}-1$ has remained stable and virulent without passage through wheat or barley since it was isolated (D. M. Weller, personal communication).

In conclusion, an overarching question that should continue to drive research on Rhizoctonia root rot and bare patch is the following: what makes these diseases so devastating in no-till fields yet makes AG-8 so fragile in its ecological fitness?

\section{ACKNOWLEDGMENTS}

We thank J. Krauser for her assistance in the preparation of the figures and tables. Mention of trade names or commercial products in this publication is solely for the purpose of providing specific information and does not imply recommendation or endorsement by the U.S. Department of Agriculture. USDA is an equal opportunity provider and employer.

\section{LITERATURE CITED}

Anderson, N. A. 1977. Evaluation of the Rhizoctonia complex in relation to seedling blight of flax. Plant Dis. Rep. 61:140-142.

Babiker, E., Hulbert, S. H., Schroeder, K. L., and Paulitz, T. C. 2011. Optimum timing of pre-plant applications of glyphosate to manage Rhizoctonia root rot in barley. Plant Dis. 95:304-310.

Bakkeren, G., Kronstad, J. W., and Lévesque, C. A. 2000. Comparison of AFLP fingerprints and ITS sequences as phylogenetic markers in Ustilaginomycetes. Mycologia 92:510-521.

Broders, K. D., Parker, M. L., Melzer, M. S., and Boland, G. J. 2014. Phylogenetic diversity of Rhizoctonia solani associated with canola and wheat in Alberta, Manitoba and Saskatchewan. Plant Dis. 98:1695-1701.

Carling, D. E., Baird, R. E., Gitaitis, R. D., Brainard, K. A., and Kuninaga, S. 2002. Characterization of AG-13, a newly reported anastomosis group of Rhizoctonia solani. Phytopathology 92:893-899.

Carling, D. E., and Leiner, R. H. 1990. Virulence of isolates of Rhizoctonia solani AG-3 collected from potato plant organs and soil. Plant Dis. 74:901-903.
Carling, D. E., Rothrock, C. S., MacNish, G. C., Sweetingham, M. W., Brainard, K. A., and Winters, S. W. 1994. Characterization of anastomosis group 11 (AG-11) of Rhizoctonia solani. Phytopathology 84:1387-1393.

Carling, D. E., and Sumner, D. R. 1992. Rhizoctonia. Pages 157-165 in: Methods for Research on Soilborne Phytopathogenic Fungi. L. L. Singleton, J. D. Mihail, and C. M. Rush, eds. The American Phytopathological Society, St Paul, MN.

Cook, R. J. 2001. Management of wheat and barley root diseases in modern farming systems. Australas. Plant Pathol. 30:119-126.

Cook, R. J., Weller, D. M., El-Banna, Y., Vakoch, D., and Zhang, H. 2002. Yield responses of direct-seeded wheat to rhizobacteria and fungicide seed treatments. Plant Dis. 86:780-784.

D'aes, J., Hoang Hua, G. K., De Maeyer, K., Pannecoucque, J., Forrez, I., Ongena, M., Dietrich, L. E. P., Thomashow, L. S., Mavrodi, D. V., and Hofte, M. 2011. Biological control of Rhizoctonia root rot on bean by phenazine and cyclic lipopeptide-producing Pseudomonas CMR12a. Phytopathology 101:996-1004.

Davis, R. A. 2005. Factors affecting occurrence and severity of Rhizoctonia root rot and Fusarium crown rot in direct-seeded cereals. M.S. thesis. Washington State University, Pullman.

Demirci, E. 1998. Rhizoctonia species and anastomosis groups isolated from barley and wheat in Erzurum, Turkey. Plant Pathol. 47:10-15.

Douglas, C. L., Rickman, R. W., Klepper, B. L., and Zuzel, J. F. 1992. Agronomic zones for dryland winter wheat producing areas of Idaho, Washington and Oregon. Northwest Sci. 66:26-34.

Douglas, C. L., Wysocki, D. J., Zuzel, J. F., Rickman, R. W., and Klepper, B. L. 1990. Agronomic zones for the dryland Pacific Northwest. A Pacific Northwest Extension Publication. PNW No. 354:1-8.

Gill, J. S., Sivasithamparam, K., and Smettem, K. R. J. 2000. Soil types with different texture affect development of Rhizoctonia root rot of wheat seedlings. Plant Soil 221:113-120.

Gonzalez Garcia, V., Portal-Onco, M. A., and Rubio, V. 2006. Biology and systematics of the form genus Rhizoctonia. Span. J. Agric. Res. 4:55-79.

Gunnell, P. S. 1986. Characteristic of the teleomorphs of Rhizoctonia oryzaesativae, Rhizoctonia oryzae, and Rhizoctonia zeae, and the effect of cultural practices on aggregate sheath spot of rice, caused by R. oryzae-sativae. Ph.D. thesis. University of California, Davis.

Harris, J. R., and Moen, R. 1985. Replacement of Rhizoctonia solani on wheat seedlings by a succession of root rot fungi. Trans. Br. Mycol. Soc. 84:11-20.

Huang, Z., Bonsall, R. F., Mavrodi, D. V., Weller, D. M., and Thomashow, L. S. 2004. Transformation of Pseudomonas fluorescens with genes for biosynthesis of phenazine-1-carboxylic acid improves biocontrol of Rhizoctonia root rot and in situ antibiotic production. FEMS Microbiol. Ecol. 49:243-251.

Hynes, H. J. 1933. "Purple patch" of wheat and oats. A disease caused by the fungus Rhizoctonia solani. Agric. Gaz. N.S.W. 44:879-883.

Hynes, H. J. 1937. Studies on Rhizoctonia root rot of wheat and oats. Dept. Agric., New South Wales, Science Bulletin No. 58.

Jabaji-Hare, S., Chamberland, H., and Charest, P. M. 1999. Cell wall alterations in hypocotyls of bean seedlings protected from Rhizoctonia stem canker by a binucleate Rhizoctonia isolate. Mycol. Res. 103:1035-1043.

Khangura, R. K., Barbetti, M. J., and Sweetingham, M. W. 1999. Characterization and pathogenicity of Rhizoctonia species on canola. Plant Dis. 83:714-721.

Kwak, Y.-S., Bakker, P. A. H. M., Glandorf, D. C. M., Rice, J. T., Paulitz, T. C., and Weller, D. M. 2009. Diversity, virulence and 2,4-diacetylphloroglucinol sensitivity of Gaeumannomyces graminis var. tritici isolates from Washington State. Phytopathology 99:472-479.

Kwak, Y.-S., Bakker, P. A. H. M., Glandorf, D. C. M., Rice, J. T., Paulitz, T. C., and Weller, D. M. 2010. Isolation, characterization and sensitivity to 2,4-diacetylphloroglucinol of isolates of Phialophora spp. from Washington wheat fields. Phytopathology 100:404-414.

Leiner, R. H., and Carling, D. E. 1994. Characterization of Waitea circinata (Rhizoctonia) isolated from agricultural soils in Alaska. Plant Dis. 78:385388.

MacNish, G. C. 1985. Methods of reducing rhizoctonia patch of cereals in Western Australia. Plant Pathol. 34:175-181.

MacNish, G. C., Carling, D. E., Sweetingham, M. W., Ogoshi, A., and Brainard, K. A. 1995. Characterisation of anastomosis group-10 (AG-10) of Rhizoctonia solani. Australas. Plant Pathol. 24:252-260.

MacNish, G. C., and Neate, S. M. 1996. Rhizoctonia bare patch of cereals: An Australian perspective. Plant Dis. 80:965-971.

Martin, S. B. 1988. Identification, isolation frequency, and pathogenicity of anastomosis groups of binucleate Rhizoctonia spp. from strawberry roots. Phytopathology 78:379-384.

Mazzola, M. 1997. Identification and pathogenicity of Rhizoctonia spp. isolated from apple roots and orchard soil. Phytopathology 87:582-587.

Mazzola, M., Wong, O. T., and Cook, R. J. 1996. Virulence of Rhizoctonia oryzae and $R$. solani AG- 8 on wheat and detection of $R$. oryzae in plant tissue by PCR. Phytopathology 86:354-360. 
Neate, S. M., and Warcup, J. H. 1985. Anastomosis grouping of some isolates of Thanatephorus cucumeris from agricultural soils in South Australia. Trans. Br. Mycol. Soc. 85:615-620.

Ogoshi, A. 1987. Ecology and pathogenicity of anastomosis and intraspecific groups of Rhizoctonia solani Kühn. Annu. Rev. Phytopathol. 25:125-143.

Ogoshi, A., Cook, R. J., and Bassett, E. N. 1990. Rhizoctonia species and anastomosis groups causing root rot of wheat and barley in the Pacific Northwest. Phytopathology 80:784-788.

Okubara, P. A., and Jones, S. S. 2011. Seedling resistance to Rhizoctonia and Pythium spp. in wheat chromosome group 4 addition lines from Thinopyrum spp. Can. J. Plant Pathol. 33:416-423.

Okubara, P. A., Schroeder, K. L., Abatzoglou, J. T., and Paulitz, T. C. 2014. Agroecological factors correlated to soil DNA concentrations of Rhizoctonia in dryland wheat production zones of Washington State, USA. Phytopathology 104:683-691.

Okubara, P. A., Schroeder, K. L., and Paulitz, T. C. 2008. Identification and quantification of Rhizoctonia solani and $R$. oryzae using real-time polymerase chain reaction. Phytopathology 98:837-847.

Okubara, P. A., Steber, C. M., DeMacon, V. L., Walther, N. L., Paulitz, T. C., and Kidwell, K. K. 2009. Scarlet-Rz1, an EMS-generated hexaploid wheat with tolerance to the soilborne necrotrophic pathogens Rhizoctonia solani AG-8 and R. oryzae. Theor. Appl. Genet. 119:293-303.

Otten, W., Harris, K., Young, I. M., Ritz, K., and Gilligan, C. A. 2004. Preferential spread of the pathogenic fungus Rhizoctonia solani through structured soil. Soil Biol. Biochem. 36:203-210.

Patzek, L. J., du Toit, L. J., Paulitz, T. C., and Jones, S. S. 2013. Stunting of onion in the Columbia Basin of Oregon and Washington caused by Rhizoctonia spp. Plant Dis. 97:1626-1635.

Paulitz, T. C. 2002. First report of Rhizoctonia oryzae on pea. Plant Dis. 86: 442.

Paulitz, T. C., Okubara, P. A., and Schillinger, W. F. 2006. First report of damping-off of canola caused by Rhizoctonia solani AG 2-1 in Washington State. Plant Dis. 90:829.

Paulitz, T. C., and Schroeder, K. L. 2005. A new method for the quantification of Rhizoctonia solani and R. oryzae from soil. Plant Dis. 89:767-772.

Paulitz, T. C., Schroeder, K. L., and Okubara, P. A. 2010a. Integrated control of soilborne pathogens of wheat. Pages 229-245 in: Plant Pathology in the 21st Century, Vol. 1. Recent Developments in Management of Plant Diseases. I. C. U. Gisi and M. Gullino, eds. Springer.

Paulitz, T. C., Schroeder, K. L., and Schillinger, W. F. 2010b. Soilborne pathogens of cereals in an irrigated cropping system: Effects of tillage, residue management, and crop rotation. Plant Dis. 94:61-68.

Paulitz, T. C., Smiley, R. W., and Cook, R. J. 2002. Insights into the prevalence and management of soilborne cereal pathogens under direct seeding in the Pacific Northwest, U.S.A. Can. J. Plant Pathol. 24:416-428.

Paulitz, T. C., Smith, J. D., and Kidwell, K. K. 2003. Virulence of Rhizoctonia oryzae on wheat and barley cultivars from the Pacific Northwest. Plant Dis. 87:51-55.

Poole, G. J., Harries, M., Hüberli, D., Miyan, S., MacLeod, W. J., Lawes, R., and McKay, A. 2015. Predicting cereal root disease in Western Australia using soil DNA and environmental parameters. Phytopathology 105:10691079.

Pumphrey, F. V., Wilkins, D. E., Hane, D. C., and Smiley, R. W. 1987. Influence of tillage and nitrogen fertilizer on Rhizoctonia root rot (bare patch) of winter wheat. Plant Dis. 71:125-127.

Roget, D. K., Neate, S. M., and Rovira, A. D. 1996. Effect of sowing point design and tillage practice on the incidence of rhizoctonia root rot, take-all and cereal cyst nematode in wheat and barley. Aust. J. Exp. Agric. 36: 683-693.
Roget, D. K., Venn, N. R., and Rovira, A. D. 1987. Reduction of rhizoctonia root rot of direct-drilled wheat by short-term chemical fallow. Aust. J. Exp. Agric. 27:425-430.

Rovira, A. D. 1986. Influence of crop rotations and tillage on Rhizoctonia bare patch of wheat. Phytopathology 76:669-673.

Samuel, G., and Garrett, S. D. 1932. Rhizoctonia solani on cereals in South Australia. Phytopathology 22:827-836.

Schillinger, W. F., and Paulitz, T. C. 2006. Reduction of Rhizoctonia bare patch in wheat with barley rotations. Plant Dis. 90:302-306.

Schroeder, K. L., Okubara, P. A., Tanbong, J. T., Lévesque, C. A., and Paulitz, T. C. 2006. Identification and quantification of pathogenic Pythium spp. from soils in eastern Washington using real-time polymerase chain reaction. Phytopathology 96:637-647.

Schroeder, K. L., and Paulitz, T. C. 2006. Root disease of wheat and barley during the transition from conventional tillage of direct seeding. Plant Dis. 90:1247-1253.

Schroeder, K. L., and Paulitz, T. C. 2008. Effect on inoculum density and soil tillage on the development and severity of Rhizoctonia root rot. Phytopathology 98:304-314.

Schroeder, K. L., and Paulitz, T. C. 2012a. First report of root rot caused by Rhizoctonia solani AG-10 on canola in Washington State. Plant Dis. 96: 584.

Schroeder, K. L., and Paulitz, T. C. 2012b. First report of a Ceratobasidium sp. causing root rot on canola in Washington state. Plant Dis. 96:591.

Sharma-Poudyal, D., Paulitz, T. C., and du Toit, L. 2015a. Stunted patches in onion bulb crops in Oregon and Washington: Etiology and yield loss. Plant Dis. 99:648-658.

Sharma-Poudyal, D., Paulitz, T. C., Porter, L., and du Toit, L. 2015b. Characterization and Pathogenicity of Rhizoctonia and Rhizoctonia-like spp. from pea crops in the Columbia Basin of Oregon and Washington. Plant Dis. 99:604-613.

Smiley, R. W., Collins, H. P., and Rasmussen, P. E. 1996. Diseases of wheat in long-term agronomic experiments at Pendleton, Oregon. Plant Dis. 80: 813-820.

Smiley, R. W., Ogg, A. G., and Cook, R. J. 1992. Influence of glyphosate on Rhizoctonia root rot, growth, and yield of barley. Plant Dis. 76:937-942.

Smiley, R. W., and Uddin, W. 1993. Influence of soil temperature on Rhizoctonia root rot ( $R$. solani AG-8 and $R$. oryzae) of winter wheat. Phytopathology 83:777-785.

Smiley, R. W., Uddin, W., Ott, S., and Rhinhart, K. E. L. 1990. Influence of flutolanil and tolclofos-methyl on root and culm diseases of winter wheat. Plant Dis. 74:788-791.

Smiley, R. W., and Wilkins, D. E. 1993. Annual spring barley growth, yield and root rot in high- and low-residue tillage systems. J. Prod. Agric. 6:270275 .

Smith, J. D., Kidwell, K. K., Evans, M. A., Cook, R. J., and Smiley, R. W. 2003a. Assessment of spring wheat genotypes for disease reaction to Rhizoctonia AG-8 in controlled environment and direct-seeded field evaluations. Crop Sci. 43:694-700.

Smith, J. D., Kidwell, K. K., Evans, M. A., Cook, R. J., and Smiley, R. W. 2003b. Evaluation of spring cereal grains and wild Triticum germplasm for resistance to Rhizoctonia solani AG-8. Crop Sci. 43:701-709.

Sweetingham, M. W., Cruickshank, R. H., and Wong, D. H. 1986. Pectic zymograms and taxonomy and pathogenicity of the Ceratobasidiaceae. Trans. Br. Mycol. Soc. 86:305-311.

Vincelli, P. C., and Herr, J. J. 1992. Two diseases of alfalfa caused by Rhizoctonia solani AG-1 and AG-4. Plant Dis. 76:1283.

Weller, D. M., Cook, R. J., MacNish, G. C., Basset, E. N., Powelson, R. L., and Peterson, R. R. 1986. Rhizoctonia root rot of small grains favored by reduced tillage in the Pacific Northwest. Plant Dis. 70:70-73. 